\title{
Anti-inflammatory effects of gallic acid in human gestational tissues in vitro
}

\author{
Caitlyn Nguyen-Ngo® ${ }^{1,2}$, Carlos Salomon ${ }^{3,4}$, Andrew Lai ${ }^{3}$, Jane C Willcox ${ }^{5}$ and \\ Martha Lappas $\mathbb{D}^{1,2}$ \\ ${ }^{1}$ Obstetrics, Nutrition and Endocrinology Group, Department of Obstetrics and Gynaecology, University of \\ Melbourne, Heidelberg, Victoria, Australia, ${ }^{2}$ Mercy Perinatal Research Centre, Mercy Hospital for Women, \\ Heidelberg, Victoria, Australia, ${ }^{3}$ Exosome Biology Laboratory, Centre for Clinical Diagnostics, University of \\ Queensland Centre for Clinical Research, Royal Brisbane and Women's Hospital, University of Queensland, \\ Brisbane, Queensland, Australia, ${ }^{4}$ Department of Clinical Biochemistry and Immunology, Faculty of Pharmacy, \\ University of Concepción, Concepción, Chile and ${ }^{5}$ Dietetics and Human Nutrition, School of Allied Health, \\ Social Services and Sport, La Trobe University, Bundoora, Victoria, Australia
}

Correspondence should be addressed to M Lappas; Email: mlappas@unimelb.edu.au

\begin{abstract}
Spontaneous preterm birth is the leading cause of neonatal mortality and morbidity globally. Activation of the maternal immune system leads to a downstream cascade of proinflammatory events that culminate in the activation of spontaneous uterine contractions and the rupture of the foetal membranes. Anti-inflammatory agents may be a novel therapeutic approach to prevent inflammation-induced myometrial contractions and premature rupture of foetal membranes. The polyphenol gallic acid has been previously shown to exert potent anti-inflammatory effects. Thus, this study aimed to determine the effect of gallic acid on proinflammatory and pro-labour mediators in cytokine-stimulated gestational tissues in vitro. In primary human cells isolated from myometrium and foetal membranes (decidua, and amnion mesenchymal and epithelial cells), gallic acid treatment suppressed inflammation-induced expression of proinflammatory cytokines and chemokines and extracellular matrix-degrading and matrixremodelling enzymes. Gallic acid also significantly inhibited inflammation-induced myometrial activation as evidenced by decreased expression of contraction-associated proteins, the uterotonic PGF $_{2 \alpha}$ and collagen cell contractility. Using a global proteomic approach, gallic acid may differentially regulate proteins associated with collagen synthesis, cell contractility and protein synthesis in primary myometrial and decidual cells. In summary, gallic acid inhibited inflammation-induced mediators involved in active labour in primary cells isolated from myometrium and foetal membranes. These in vitro studies suggest that the polyphenol gallic acid may be able to suppress the production of proinflammatory and pro-labour mediators involved in myometrial contractions and rupture of foetal membranes. Future preclinical studies may elucidate the efficacy of gallic acid in preventing inflammation-driven preterm birth.

Reproduction (2020) 160 561-578
\end{abstract}

\section{Introduction}

Spontaneous preterm birth is a global health issue affecting 15 million pregnancies every year (Beck et al. 2010). The most critical consequence is neonatal death, accounting for 1 million neonatal deaths worldwide (Blencowe et al. 2012). Survivors of preterm birth also face significant long-term neurological morbidity, including cerebral palsy, developmental delay, and hearing and visual impairment (Mwaniki et al. 2012).

Spontaneous preterm birth shares the common terminal pathways with normal parturition, including uterine activation and rupture of membranes. The triggers, however, differ with infection and inflammation associated with half of all preterm births (Goldenberg et al. 2000). Bacterial endotoxins or proinflammatory insults activate the maternal immune system to drive leukocyte infiltration into the gestational tissues (Thomson et al. 1999, Hamilton et al. 2012). The infiltrating immune cells then induce production of proinflammatory cytokines, such as interleukin (IL)-1B and TNF, which further propagate inflammation (Lappas et al. 2006, Lappas 2017) and production of other pro-labour mediators (Rauk \& Chiao 2000, Kumar et al. 2006). Inflammation induces contractionassociated proteins, uterotonics, and extracellular matrix (ECM) degrading and remodelling enzymes, ultimately resulting in myometrial contractions and 
foetal membrane rupture associated with spontaneous preterm birth (Vadillo-Ortega \& Estrada-Gutierrez 2005, Olson \& Ammann 2007). Similarly, oxidative stress is present in the foetal membranes (Chai et al. 2012) and is thought to contribute to the development of pPROM and preterm birth (Moore et al. 2018). Unfortunately, current interventions provide limited assistance for inflammation-driven preterm birth. Progesterone is effective only in women with a short cervix, while tocolytic therapies delay preterm birth for only $48 \mathrm{~h}$ and present little neonatal benefit (Haas et al. 2012). Antibiotic use is also effective for women with pPROM (Kenyon et al. 2013); however, little evidence exists to demonstrate an effect of antibiotics against myometrial contractions in preterm labour (Flenady et al. 2013).

Polyphenols are natural, plant-based compounds that have demonstrated anti-inflammatory properties and are categorised into four key groups, including flavonoids, stilbenes, lignans and phenolic acids (Manach et al. 2004). Our previous studies have shown that polyphenols belonging to the flavonoids (nobiletin, naringenin, apigenin, silibinin, luteolin and kaempferol), lignans (honokiol) and phenolic acids (curcumin) can suppress inflammation-induced expression of proinflammatory cytokines, chemokines, prostaglandins and ECM-degrading enzymes in placenta, myometrium and foetal membranes (Lim et al. 2013c, 2014, Wall et al. 2013, Morwood \& Lappas 2014, Wijesuriya \& Lappas 2018). Notably, recent epidemiological studies demonstrate that plant-based diets, and specifically high consumption of raisins, are associated with reduced incidence of preterm birth (Myhre et al. 2013, Englund-Ogge et al. 2014). Raisins are a rich source of the phenolic acid gallic acid (Shao et al. 2016) which possesses potent anti-inflammatory properties in several laboratory (Choi et al. 2009, Lee et al. 2015) and animal models of inflammation (Hsiang et al. 2013, Pandurangan et al. 2015). There are no studies, however, that have investigated the anti-inflammatory potential of the phenolic acid gallic acid in human gestational tissue in the context of spontaneous preterm birth.

In this study, we sought to determine the effect of gallic acid on: (1) proinflammatory cytokines and chemokines, (2) myometrial cell contractility and the prostaglandin pathway, and (3) ECM-degrading and ECM-remodelling enzymes. To assess this, we used primary human cells isolated from pregnant non-labouring myometrium and foetal membranes (decidua, amnion mesenchymal and amnion epithelial), and incubated the cells with the proinflammatory cytokines IL1B or TNF to generate an in vitro model of intrauterine inflammation. Myometrial cells and decidual cells were also used for label-free quantitative mass spectrometry and bioinformatics analysis to identify potential signalling pathways through which gallic acid may exert its effects.

\section{Methods and materials}

\section{Human tissue collection}

Ethics approval was obtained from the Mercy Hospital for Women's Research and Ethics Committee (Mercy Health, Ethics approval number R04-29) and written informed consent was obtained from all participating subjects. Myometrium and foetal membranes were obtained from healthy women with a BMI $<30 \mathrm{~kg} / \mathrm{m}^{2}$ on the day of term Caesarean section (37-41 weeks of gestation). All samples were obtained from women who had no clinical signs of infection. Indications for Caesarean section in the absence of labour were breech presentation and/or previous Caesarean section. The following exclusion criteria were applied: vascular/ renal complication, multiple gestations, asthma, smokers, preeclampsia, chorioamnionitis, placental abruption, acute foetal distress and women with any other adverse underlying medical conditions. All tissues were processed within 15 min of delivery.

\section{Primary cell culture}

Myometrial cells (Lim et al. 2013a), amnion epithelial and mesenchymal cells (Lim \& Lappas 2019) and decidual cells (Araujo et al. 2018) were isolated and cultured as previously described. Cells were cultured in DMEM/F-12 containing $100 \mathrm{U} / \mathrm{mL}$ penicillin, $100 \mu \mathrm{g} / \mathrm{mL}$ streptomycin and $10 \%$ NBS (for myometrial cells) or $10 \%$ FBS (for amnion and decidual cells), until they reached $80 \%$ confluency. Cells were then split into 48-well tissue culture plates and at approximately $80 \%$ confluence were treated with $100 \mu \mathrm{M}$ gallic acid or vehicle control $(0.1 \%(\mathrm{v} / \mathrm{v})$ DMSO) with or without $1 \mathrm{ng} / \mathrm{mL}$ IL1B or $10 \mathrm{ng} / \mathrm{mL}$ TNF for $20 \mathrm{~h}$. The optimised dose of gallic acid was based on previous studies in other cells (Hsiang et al. 2013, Pandurangan et al. 2015) and a dose-response test (data not shown). After a 20-h incubation, cells were collected and stored at $-80^{\circ} \mathrm{C}$ for analysis of pro-labour mediators by RT-quantitative PCR (RT-qPCR) ( $n=6$ patients) or quantitative mass spectrometry ( $n=6$ patients) as detailed subsequently. The incubation medium was collected and stored at $-20^{\circ} \mathrm{C}$ for analysis of pro-labour mediators by ELISA ( $n=6$ patients) or gelatin zymography ( $n=5$ patients).

\section{ELISA}

Media from the tissue explants were assayed using a sandwich ELISA to determine the protein concentrations of IL6, GM-CSF and CXCL8 (Life Technologies) and IL1A, IL1B, CCL2, CXCL1 and CXCL5 (R\&D Systems) as according to the manufacturer's instructions. The release of PGF $_{2 \alpha}$ into the incubation medium was also assayed using a commercially available competitive enzyme immunoassay kit according to the manufacturer's instructions (Cayman Chemical Company). The 
calculated interassay and intraassay coefficients of variation $(\mathrm{CV})$ were all less than $10 \%$.

\section{RNA extraction and quantitative RT-PCR ( $q R T-P C R)$}

Total RNA was extracted from tissues and converted to cDNA as previously described (Wijesuriya \& Lappas 2018). The cDNA was diluted to $1 \mathrm{ng} / \mu \mathrm{L}$ in sterile milli-Q water. The SensiFASTTM SYBR No-ROX Kit (Bioline, Alexandria, NSW, Australia) and $100 \mathrm{nM}$ of pre-designed and validated primers (Qiagen) were used to perform RT-PCR on CFX384 Real-Time PCR detection system from Bio-Rad Laboratories (Gladesville, NSW, Australia). Average gene $\mathrm{Ct}$ values were normalised against the housekeeping genes succinate dehydrogenase complex subunit A (SDHA) and tyrosine 3-monooxygenase/ tryptophan 5-monooxygenase activation protein zeta (YWHAZ). There was no effect of experimental treatment on SDHA or YWHAZ mRNA expression. Fold differences were determined using the comparative $\mathrm{Ct}$ method.

\section{Collagen gel contraction assay}

Myometrial cell contraction assays were performed as previously described (Wijesuriya \& Lappas 2018). Primary human myometrial cells (isolated as detailed above) were resuspended in $0.25 \mathrm{~mL}$ DMEM/F12 (containing $10 \%$ NBS) and mixed with $40 \mu \mathrm{L}$ collagen ( $3 \mathrm{mg} / \mathrm{mL}$ collagen I from rat protein solution; Gibco ${ }^{\mathrm{TM}}$ ) and $1 \mu \mathrm{L} 1 \mathrm{M} \mathrm{NaOH}$ by gently pipetting. The mixture was transferred to 48-well tissue culture plates, incubated at $37^{\circ} \mathrm{C}$ for $30 \mathrm{~min}$ to allow polymerisation and then treated with $10 \mathrm{ng} / \mathrm{mL}$ TNF with or without $100 \mu \mathrm{M}$ gallic acid. The gel matrix was gently detached from the well, incubated for $50 \mathrm{~h}$ at $37^{\circ} \mathrm{C}$, and the area of the gel was determined using Image Lab 3.0 (BioRad Laboratories). Experiments were performed from myometrium obtained from five patients.

\section{Gelatin zymography}

Media was used to assess matrix metalloproteinase (MMP) 9 activity using gelatin zymography as previously described (Lim et al. 2013b). Proteolytic activity was visualised as clear zones of lysis on a blue background of undigested gelatin. Gels were scanned using a ChemiDoc XRS system (Bio-Rad Laboratories), and densitometry was performed on inverted images using Image Lab 3.0 (Bio-Rad Laboratories).

\section{Quantitative mass spectrometry}

Mass spectrometry analyses were conducted within an ISO17025 accredited (National Association of Testing Authorities, Australia) research facility, as previously described (Jayabalan et al. 2019). Protein extraction was performed on human primary myometrial and decidual cells using $25 \mu \mathrm{L}$ radioimmunoprecipitation assay (RIPA) lysis buffer (Sigma) supplemented with protease inhibitor (Roche). After sonication for $5 \mathrm{~min}$, the resulting cell lysates were clarified by centrifugation at $8000 \mathrm{~g}$ for $10 \mathrm{~min}$. The protein concentrations were estimated using a bicinchoninic acid assay kit according to the manufacturer's instruction (Thermo). Filter Aided Sample Preparation: The cell lysates were processed for mass spectrometry using the filter aided sample preparation (FASP) method (Barr et al. 2011). In brief, 8 $\mu \mathrm{g}$ of proteins from each cell lysate sample were diluted with urea buffer (8 M urea, $100 \mathrm{mM}$ Tris, pH 8.5).

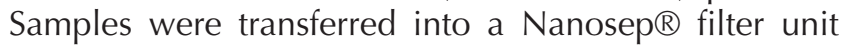
with a $30 \mathrm{~K}$ molecular weight cut off and centrifuged for $10,000 \mathrm{~g}$ for $15 \mathrm{~min}$ and flow-through discarded. Proteins were reduced with $100 \mathrm{mM}$ dithiothreitol, washed with urea buffer and alkylated with $50 \mathrm{mM}$ iodoacetamide. The samples were equilibrated with 50 $\mathrm{mM}$ ammonium bicarbonate and digested using $1 \mu \mathrm{g}$ of trypsin overnight at $37^{\circ} \mathrm{C}$. Desalting: The tryptic peptides from individual samples were desalted with $0.1 \%(\mathrm{v} / \mathrm{v})$ trifluoroacetic acid (TFA) in water using SOLA $\mu$ HRP SPE 96-well plate (Thermo Fisher Scientific) according to the manufacturer's instructions. Analysis of peptides: The peptides were then processed in an informationdependent acquisition (IDA) manner on an $\mathrm{AB}$ Sciex 5600 TripleTOF mass spectrometer. For SWATH acquisition on individual samples, the TripleTOF® 5600 System was configured as described by Gillet et al. (Catalano \& Ehrenberg 2006). Data Processing: To generate the local ion library, a protein database search was conducted using the ProteinPilot version 4.5b Software (AB SCIEX) and the Paragon ${ }^{\mathrm{TM}}$ Algorithm. The search was performed against the SwissProt Homo sapiens database with a global false discovery rate (FDR) of $1 \%$ used as the threshold for the number of proteins for import. The SWATH Acquisition Microapp 2.0 in PeakView 2.2 (SCIEX) was used to process raw SWATH data files. Processing settings for the SWATH Microapp include two peptides per protein, three transitions per peptide, peptide confidence threshold corresponding to $1 \%$ global FDR and FDR threshold of $1 \%$. The resulting peak area for each protein after SWATH processing was exported to MarkerView 1.3.1 (SCIEX) for statistical analysis and the resulting data normalised using the Total Area Sums (TAS) approach.

\section{Ingenuity pathway analysis (IPA)}

Pathway enrichment analyses were performed with Ingenuity Pathway Analysis (IPA, Qiagen) as we previously described (Nguyen-Ngo et al. 2020). IPA was performed to identify canonical pathways, diseases and functions, and protein networks associated with significantly changed proteins. Statistical significance of enriched pathways for the proteins and pathways were denoted with $P$-value $<0.05$. 


\section{Statistical analysis}

All statistical analyses were undertaken using GraphPad Prism (GraphPad Software). Shapiro-Wilk test was used to test the normality of all the data. Data for Figs 1, $2,3,4,5,6,7,8$ and 9 were analysed by a repeated measures one-way ANOVA (with LSD post hoc testing to discriminate among the means); data for Fig. 10 was analysed by Student's $t$-test; non-normally distributed data were logarithmically transformed before analysis. Statistical significance was ascribed to a $P$-value $\leq 0.05$. Data were expressed as mean \pm S.E.M.

\section{Results}

\section{Effect of gallic acid on proinflammatory cytokines in myometrial, decidual and amnion cells}

The effect of gallic acid on proinflammatory cytokine expression and secretion in primary human myometrial, decidual and amnion mesenchymal cells is shown in Figs 1, 2 and 3. For all cells, IL1B-induced IL1B mRNA expression and TNF-induced GM-CSF secretion were non-detectable. Further, IL1A and IL1B levels in the incubation media were also below the sensitivity of the assay for all cells. In amnion epithelial cells, for the majority of the patients, IL6 and CCL2 levels in the incubation media of amnion epithelial cells were also below the sensitivity of the assay. Thus, no further inflammatory analysis was conducted on amnion epithelial cells.

IL1B or TNF treatment significantly increased IL1A, IL1B, IL6 and GM-CSF mRNA expression and protein secretion compared to basal in myometrial cells (Fig. 1), decidual cells (Fig. 2) and amnion mesenchymal cells (Fig. 3). In myometrial cells, co-treatment with gallic acid significantly suppressed IL1B- and TNFinduced IL1A, IL6 and GM-CSF mRNA expression and IL6 secretion (Fig. 1A, C, D and E). There was no effect of gallic acid on TNF-induced IL1B mRNA expression or GM-CSF secretion (Fig. 1B and F). In decidual cells, co-treatment with gallic acid significantly suppressed IL1B- and TNF-induced IL1A (Fig. 2A), IL1B (Fig. 2B), IL6 (Fig. 2C) and GM-CSF (Fig. 2E) mRNA expression, and IL6 (Fig. 2D) and GM-CSF secretion (Fig. 2F). In amnion mesenchymal cells, gallic acid significantly suppressed II1B- and TNF-induced IL6 mRNA expression and secretion (Fig. 3C and D). There was, however, no effect of gallic acid on IL1B- or TNF-induced IL1A, IL1B and GM-CSF mRNA expression or secretion (Fig. 3A, B, E and $\mathrm{F}$ ).

\section{Effect of gallic acid on IL1B- and TNF-induced proinflammatory chemokines in cells isolated from the myometrium and the foetal membranes}

The effect of gallic acid on IL1B- or TNF-induced CCL and $\mathrm{CXCL}$ chemokine expression and secretion in primary human myometrial, decidual and amnion mesenchymal cells is depicted in Figs 4, 5 and 6, respectively. For all cells, CCL8 levels in the incubation media were below the sensitivity of the assay.

Treatment with IL1B or TNF significantly increased CCL2, CCL8, CXCL1, CXCL5 and CXCL8 mRNA expression and secretion compared to basal in
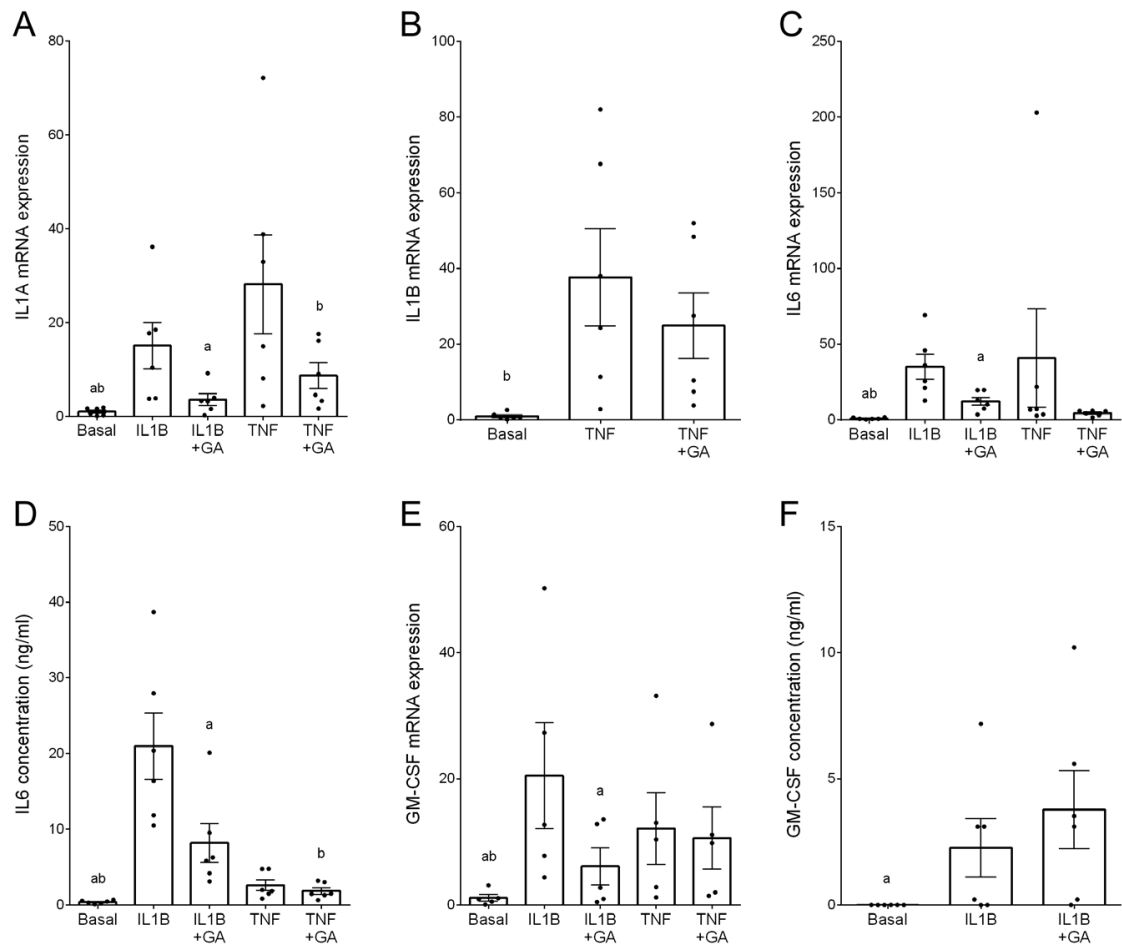

Figure 1 Effect of gallic acid on IL1B- and TNF-induced proinflammatory cytokines in human primary myometrial cells. Human primary myometrial cells were incubated in $1 \mathrm{ng} / \mathrm{mL}$ IL1B or $10 \mathrm{ng} / \mathrm{mL}$ TNF with or without $100 \mu \mathrm{M}$ gallic acid (GA) for $20 \mathrm{~h}$ ( $n=6$ patients). (A, B, C and E) IL1A, IL1B, IL6, and GM-CSF mRNA expression were analysed by RT-qPCR. ( $\mathrm{D}$ and F) The concentrations of IL6 and GM-CSF in the incubation medium were assayed by ELISA. For all graphs, each data point represents an individual patient and the bars represent the mean \pm S.E.M. ${ }^{\text {a }} P \leq 0.05$ vs IL1B; ${ }^{\mathrm{b}} P \leq 0.05$ vs TNF; repeated measures one-way ANOVA. 

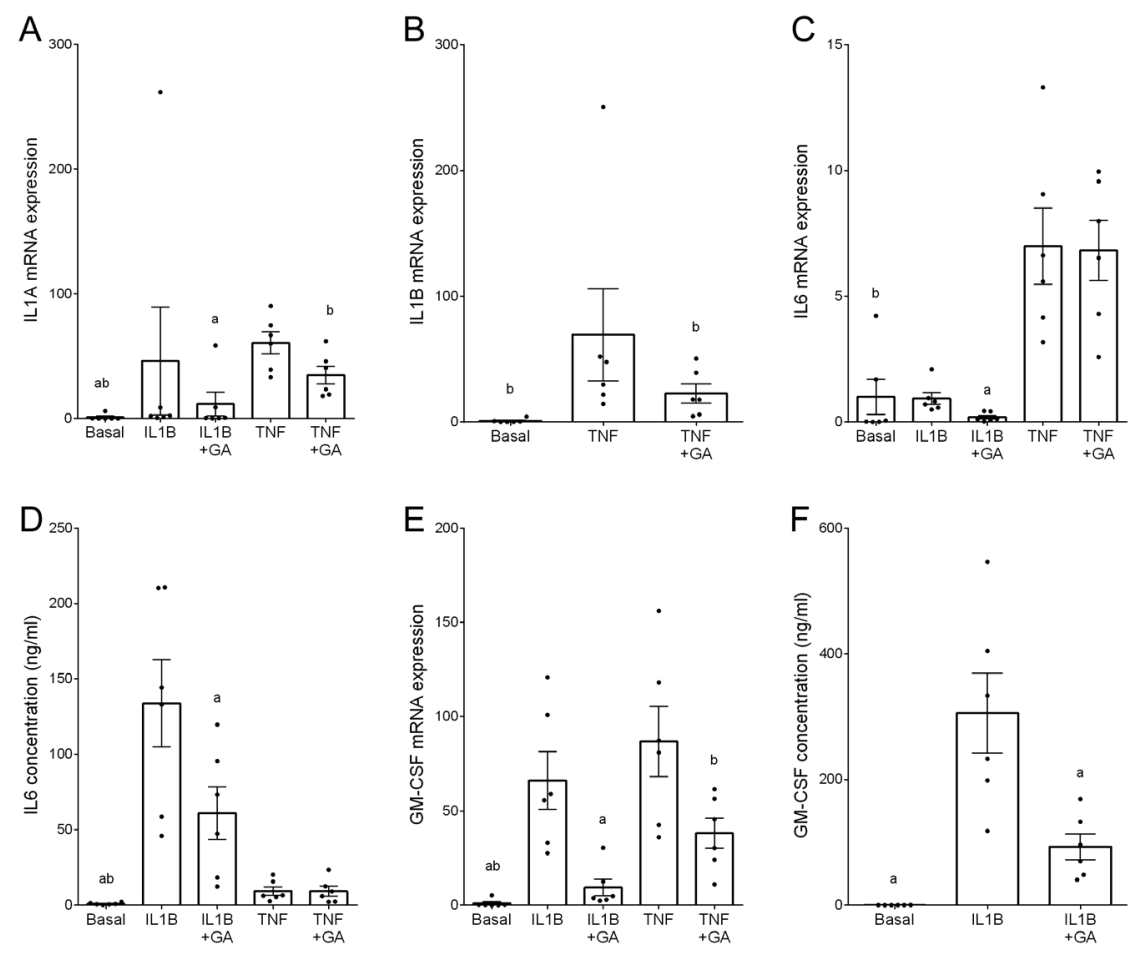

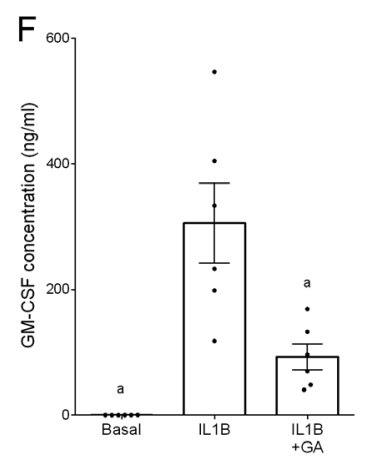

Figure 2 Effect of gallic acid on IL1B- and TNF-induced proinflammatory cytokines in human primary decidual cells. Human primary decidual cells were incubated in $1 \mathrm{ng} / \mathrm{mL}$ IL1B or $10 \mathrm{ng} / \mathrm{mL}$ TNF, with or without $100 \mu \mathrm{M}$ gallic acid (GA) for $20 \mathrm{~h}$ ( $n=6$ patients). (A, B, C and E) IL1A, IL1B, IL6, and GM-CSF mRNA expression were analysed by RT-qPCR. (D and F) The concentrations of IL6 and GM-CSF in the incubation medium were assayed by ELISA. For all graphs, each data point represents an individual patient and the bars represent the mean \pm S.E.M. ${ }^{a} P \leq 0.05$ vs IL1B; ${ }^{b} P \leq 0.05$ vs TNF; repeated measures one-way ANOVA. myometrial cells (Fig. 4), decidual cells (Fig. 5) and amnion mesenchymal cells (Fig. 6). In myometrial cells, co-treatment with gallic acid significantly suppressed CCL2, CXCL1, CXCL5 and CXCL8 mRNA expression and protein secretion compared to IL1B and TNF treatment (Fig. 4A, B, D, E, F, G, H and I). There was, however, no effect of gallic acid on CCL8 mRNA expression compared with IL1B or TNF (Fig. 4C).
In decidual cells, gallic acid significantly reduced CCL2, CXCL1, CXCL5 and CXCL8 mRNA expression and protein secretion compared to IL1B and TNF treatment (Fig. 5A, B, E, F, G, H and I). There was no effect of gallic acid on CCL8 (Fig. 5C) or CXCL1 (Fig. 5D) mRNA expression compared with IL1B or TNF.

In amnion mesenchymal cells, gallic acid treatment significantly suppressed CXCL8 mRNA expression and
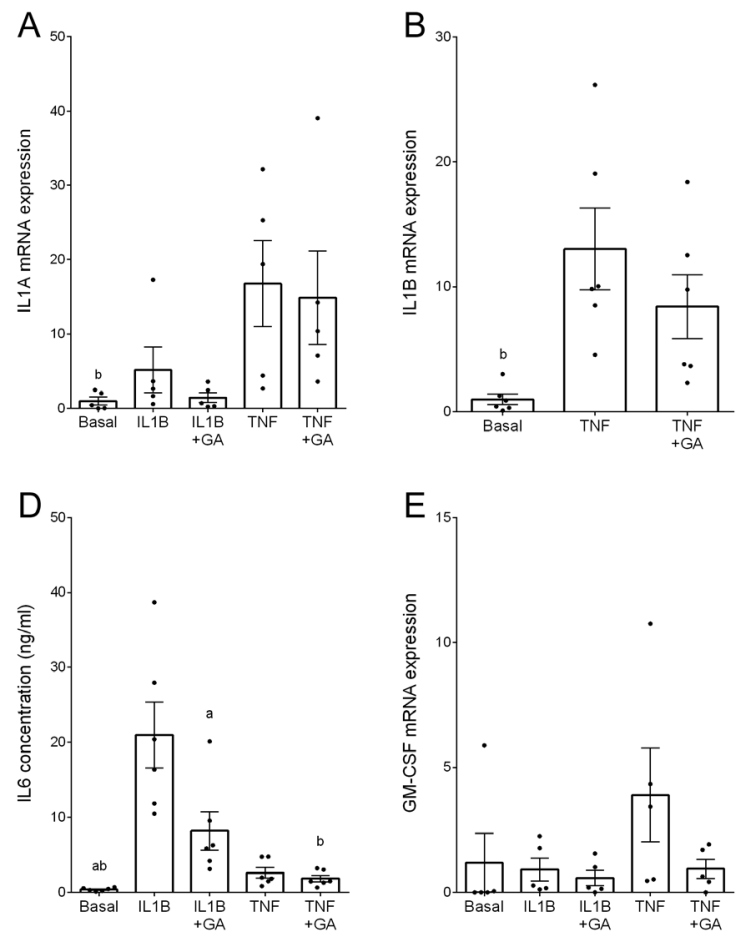
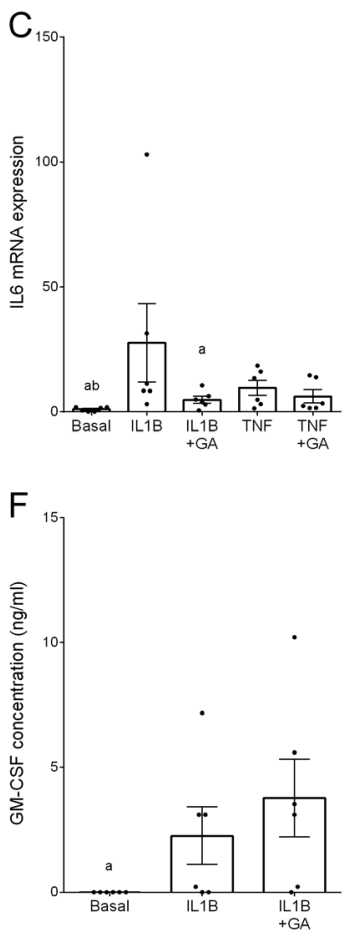

Figure 3 Effect of gallic acid on IL1B- and TNF-induced proinflammatory cytokines in human primary amnion mesenchymal cells. Human primary amnion mesenchymal cells were incubated in $1 \mathrm{ng} / \mathrm{mL}$ IL1B or $10 \mathrm{ng} / \mathrm{mL}$ TNF, with or without $100 \mu \mathrm{M}$ gallic acid (GA) for $20 \mathrm{~h}$ ( $n=6$ patients). (A, B, C and E) IL1A, IL1B, IL6, and GM-CSF mRNA expression were analysed by RT-qPCR. ( $D$ and F) The concentrations of IL6 and GM-CSF in the incubation medium were assayed by ELISA. For all graphs, each data point represents an individual patient and the bars represent the mean \pm S.E.M. ${ }^{\text {a } P} \leq 0.05$ vs IL $1 B ;{ }^{b} P \leq 0.05$ vs TNF; repeated measures one-way ANOVA. 

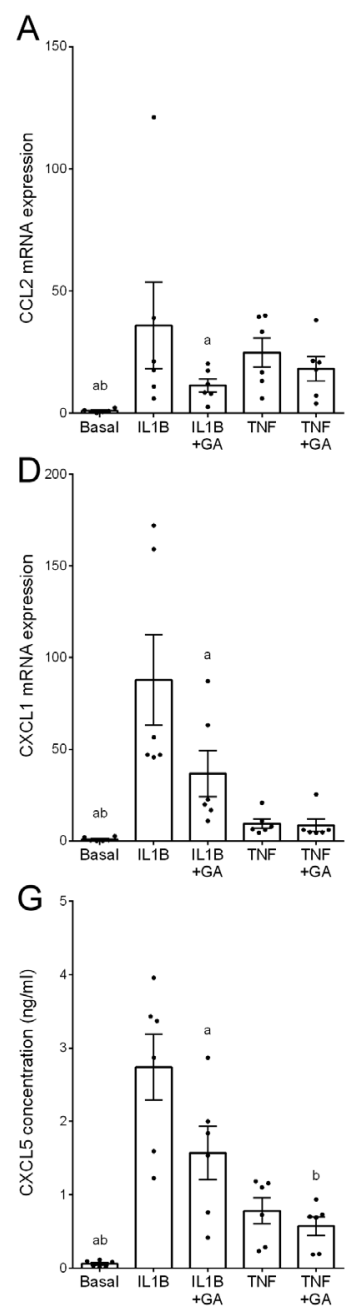
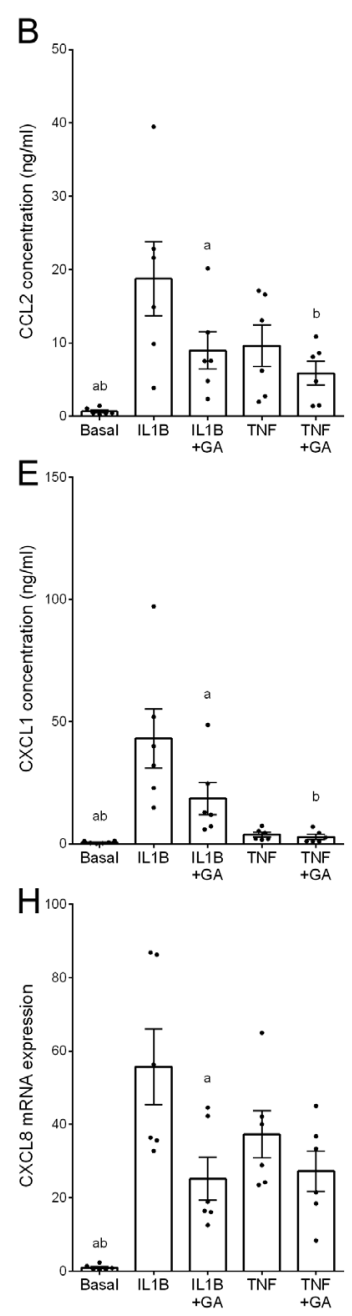
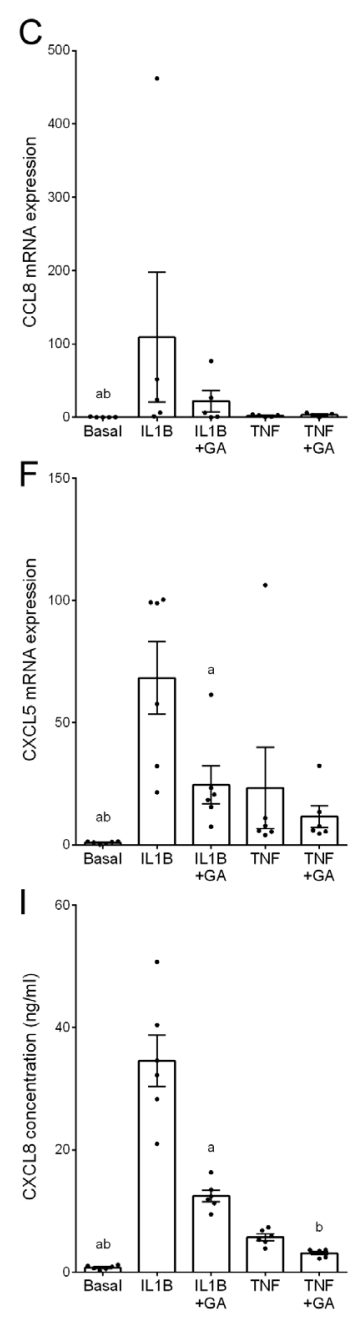

Figure 4 Effect of gallic acid on IL1B- and TNF-induced proinflammatory chemokines in human primary myometrial cells. Human primary myometrial cells were incubated in $1 \mathrm{ng} / \mathrm{mL}$ IL1B or $10 \mathrm{ng} / \mathrm{mL}$ TNF, with or without $100 \mu \mathrm{M}$ gallic acid (GA) for $20 \mathrm{~h}$ ( $n=6$ patients). (A, C, D, F and H) CCL2, CCL8, CXCL1, CXCL5 and CXCL8 mRNA expression were analysed by RT-qPCR. (B, E, $\mathrm{G}$ and I) The concentrations of CCL2, CXCL1, CXCL5 and CXCL8 in the incubation medium were assayed by ELISA. For all graphs, each data point represents an individual patient and the bars represent the mean \pm S.E.M. ${ }^{\text {a }} P \leq 0.05$ vs IL1B; ${ }^{\mathrm{b}} P \leq 0.05$ vs TNF; repeated measures one-way ANOVA.
CCL2, CXCL1, CXCL5 and CXCL8 protein secretion compared with IL1B or TNF (Fig. 6B, E, G, H and I). There was, however, no effect on IL1B- or TNF-induced CCL2, CCL8, CXCL1 and CXCL5 mRNA expression (Fig. $6 \mathrm{~A}, \mathrm{C}, \mathrm{D}$ and $\mathrm{F})$.

\section{Effect of gallic acid on MMP expression in human primary decidua and amnion cells}

ECM degrading and remodelling enzymes are key mediators involved in the rupture of foetal membranes during parturition. Amnion epithelial cells are major producers of MMP9, where preterm and term labour foetal membranes were found to express higher concentrations of MMP9 than their not-in-labour counterparts (Xu et al. 2002). Similar cytokine-induced enzymes, such as MMP1, MMP3 and MMP13, are also thought to act on different cell populations within the foetal membranes, including amnion epithelial, amnion mesenchymal and decidual cells, to facilitate foetal membrane weakening (Weiss et al. 2007). Thus, human primary decidual cells and amnion (mesenchymal and epithelial) cells were treated with IL1B or TNF in the presence or absence of gallic acid to determine the effect of gallic acid on MMP1, MMP3, MMP9 and MMP13 mRNA expression, as well as secreted proMMP9 expression.

IL1B or TNF stimulation significantly increased MMP1 and MMP9 mRNA expression, and pro-MMP9 expression compared with basal in decidual (Fig. 7A, $\mathrm{C}$ and $\mathrm{D}$ ), amnion mesenchymal (Fig. 7F, G and $\mathrm{H}$ ) and amnion epithelial cells (Fig. 7J and K). There was no effect of IL1B or TNF on MMP3 or MMP13 mRNA expression compared with basal in decidual or amnion mesenchymal cells (Fig. 7B, E and I). In decidual cells, gallic acid co-treatment significantly blunted IL1Binduced MMP1 and MMP13 (Fig. 7A and E) mRNA expression, and IL1B- and TNF-induced proMMP9 expression (Fig. 7D). There was no effect of gallic acid on IL1B- or TNF-induced MMP3 and MMP9 mRNA expression (Fig. 7B and C). In amnion mesenchymal cells, gallic acid treatment significantly reduced MMP9 and MMP13 mRNA expression compared with TNF (Fig. 7G and I). However, there was no effect of gallic acid on MMP1 mRNA expression compared with IL1B or TNF (Fig. 7F). There was also no effect of gallic acid on 

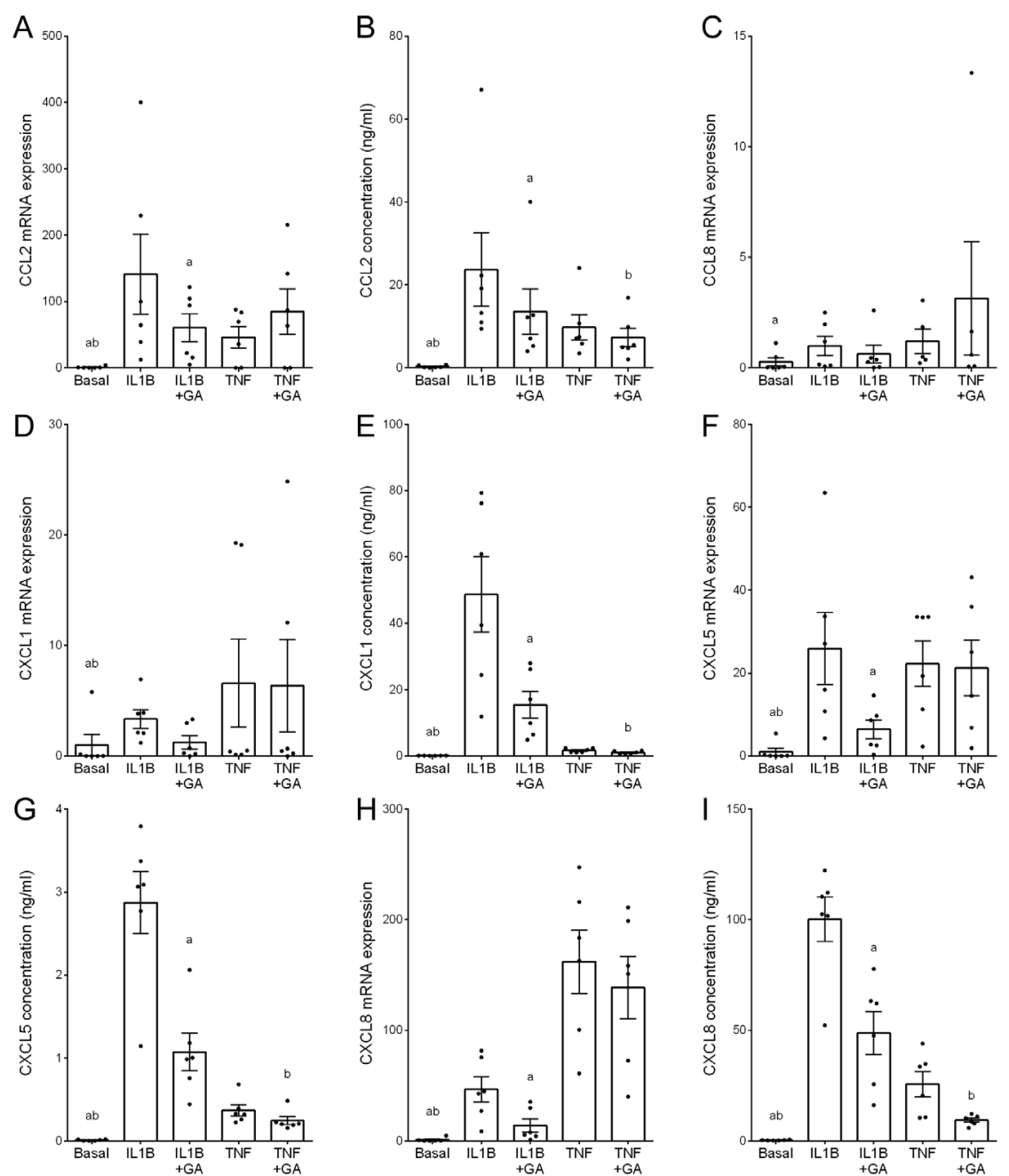

Figure 5 Effect of gallic acid on IL1B- and TNF-induced proinflammatory chemokines in human primary decidual cells. Human primary decidual cells were incubated in $1 \mathrm{ng} /$ $\mathrm{mL}$ IL1B or $10 \mathrm{ng} / \mathrm{mL}$ TNF, with or without $100 \mu \mathrm{M}$ gallic acid (GA) for $20 \mathrm{~h}(n=6$ patients). (A, C, D, F and H) CCL2, CCL8, CXCL1, CXCL5 and CXCL8 mRNA expression were analysed by RT-qPCR. (B, E, G and I) The concentrations of CCL2, CXCL1, CXCL5 and CXCL8 in the incubation medium were assayed by ELISA. For all graphs, each data point represents an individual patient and the bars represent the mean \pm S.E.M. ${ }^{\text {a }} P \leq 0.05$ vs IL1B; ${ }^{\mathrm{b}} P \leq 0.05$ vs TNF; repeated measures one-way ANOVA.
pro-MMP9 expression compared with IL1B or TNF (Fig. 7H). MMP3 mRNA expression in amnion mesenchymal cells was non-detectable. In epithelial cells, gallic acid co-treatment reduced IL1B-induced proMMP9 expression (Fig. 7K). There was no effect of gallic acid on IL1B- or TNF-induced MMP9 mRNA expression (Fig. 7J). MMP1, MMP3 and MMP13 mRNA expression in amnion epithelial cells were non-detectable.

\section{Effect of gallic acid on COX-2-prostaglandin pathway}

Prostaglandin synthase (PTGS2) is the limiting factor in the synthesis of prostaglandin (PG) $\mathrm{F}_{2 \alpha}$ (Olson 2003). $\mathrm{PGF}_{2 \alpha}$ then binds with its prostaglandin $\mathrm{F}$ receptor (PTGFR) to induce myometrial contractility (Olson 2003) and induce the expression of proinflammatory mediators (Leimert et al. 2019). In this study, treatment with IL1B or TNF significantly increased PTGS2 and PTGFR mRNA expression and the release of $\mathrm{PGF}_{2 \alpha}$ in myometrial cells, compared with basal (Fig. 8A, B and C). The effect of gallic acid was a significant decrease in IL1Binduced PTGS2 mRNA expression and PGF $_{2 \alpha}$ release (Fig. 8A and B). Gallic acid also reduced TNF-induced
$\mathrm{PGF}_{2 \alpha}$ release (Fig. $8 \mathrm{~B}$ ). On the other hand, there was no effect on TNF-induced PTGS2 mRNA expression (Fig. 8A). There was also no effect of gallic acid on either IL1Bor TNF-induced PTGFR mRNA expression (Fig. 8C).

Decidua is also a source of prostaglandins that interacts with myometrial cells to induce uterine activation (Skinner \& Challis 1985). Gallic acid co-treatment significantly reduced decidual IL1B-induced PTGS2 mRNA expression and $\mathrm{PGF}_{2 \alpha}$ release (Fig. $8 \mathrm{E}$ and $\mathrm{F}$ ). There was, however, no effect of gallic acid on TNFinduced PTGS2 mRNA expression and $\mathrm{PGF}_{2 \alpha}$ release (Fig. $8 \mathrm{E}$ and F).

\section{Effect of gallic acid on myometrial cell contractility}

Due to the inhibitory effect of gallic acid on the expression of PTGS2 and secretion of uterotonic prostaglandin $\mathrm{PGF}_{2 \alpha}$ in myometrial cells, we assessed the effect of gallic acid on myometrial cell contractility using a 3D collagen gel assay (Fig. 9). For these studies, human primary myometrial cells were embedded in collagen gels and incubated in TNF with or without gallic acid. TNF treatment significantly reduced collagen 

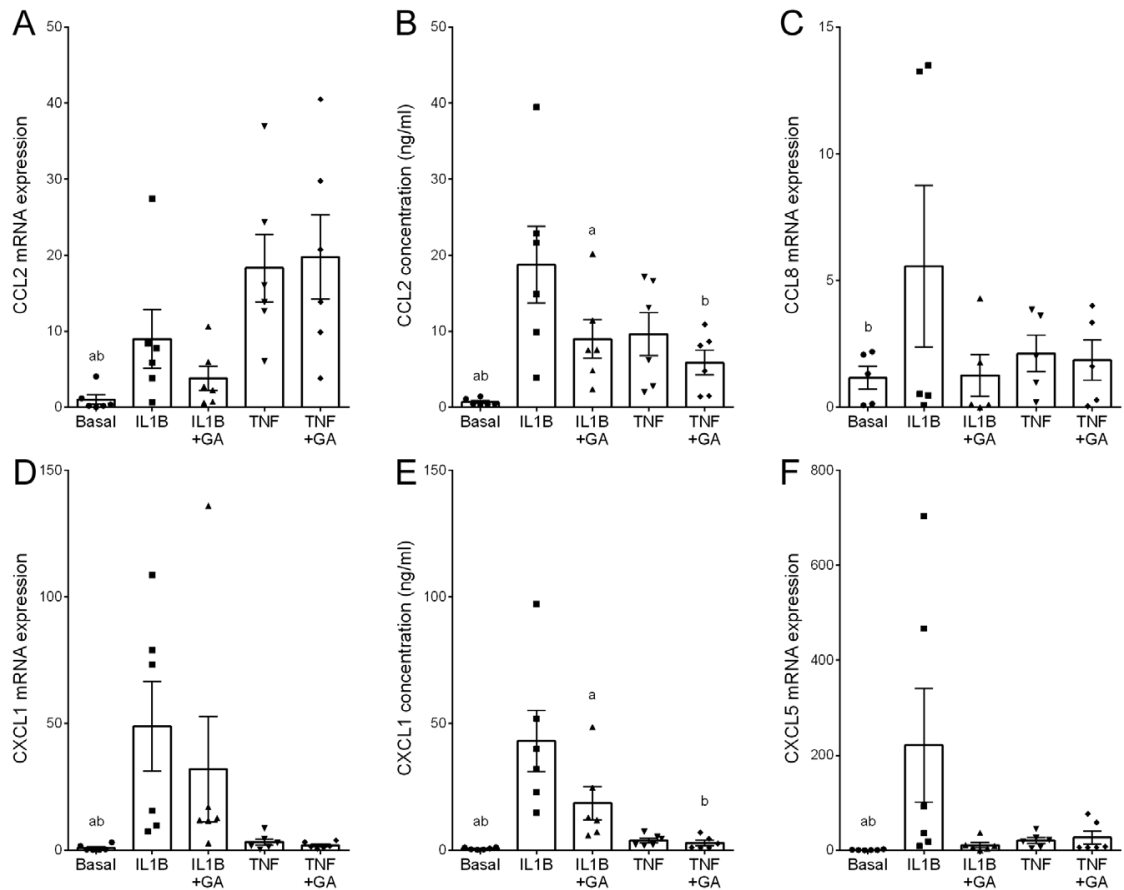

Figure 6 Effect of gallic acid on IL1B- and TNF-induced proinflammatory chemokines in human primary amnion mesenchymal cells. Human primary amnion mesenchymal cells
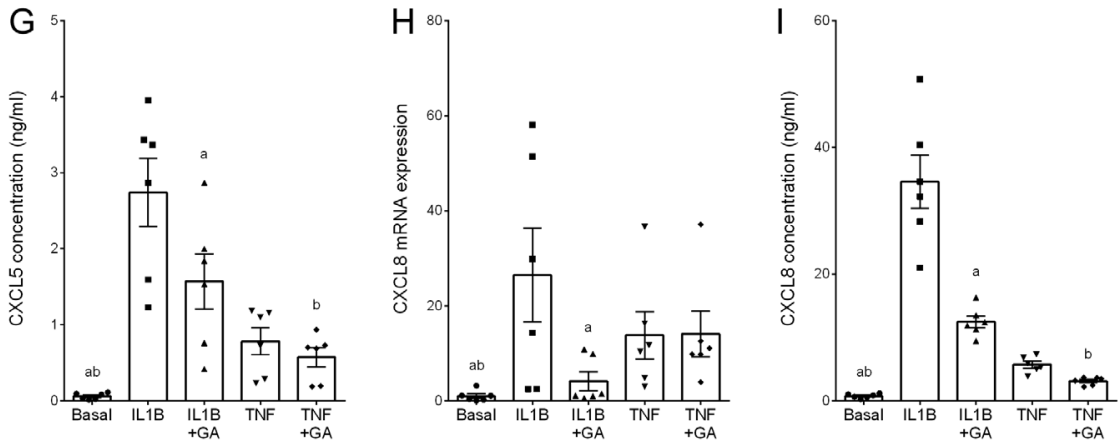
were incubated in $1 \mathrm{ng} / \mathrm{mL}$ IL1B or $10 \mathrm{ng} / \mathrm{mL}$ TNF, with or without $100 \mu \mathrm{M}$ gallic acid (GA) for $20 \mathrm{~h}$ ( $n=6$ patients). (A, C, D, F and $\mathrm{H}$ ) CCL2, CCL8, CXCL1, CXCL5 and CXCL8 mRNA expression were analysed by RT-qPCR (B, E, G and I) The concentrations of CCL2, CXCL1, CXCL5 and CXCL8 in the incubation medium were assayed by ELISA. For all graphs, each data point represents an individual patient and the bars represent the mean \pm S.E.M. ${ }^{\mathrm{a} P} \leq 0.05$ vs IL $1 \mathrm{~B} ;{ }^{\mathrm{b}} P \leq 0.05$ vs TNF; repeated measures one-way ANOVA.

gel area compared with basal by $57.8 \%$, demonstrating increased contraction of the myometrial cells (Fig. 9A). Co-treatment with $100 \mu \mathrm{M}$ gallic acid prevented this shrinkage by $49.2 \%$ compared with TNF, indicating suppressed myometrial cell contractility. We also assessed the effect of lower concentrations of gallic acid on myometrial contractility and the data are presented in Fig. 9B. Co-treatment with 25 and $50 \mu \mathrm{M}$ gallic also significantly reversed TNF-induced shrinkage by 48 and $52.7 \%$, respectively.

\section{Effect of gallic acid on the global protein profile of primary human myometrial and decidual cells}

Finally, we sought to identify the potential mechanistic signalling pathways that gallic acid may act through in primary myometrial and decidual cells. Informationdependent acquisition (IDA) and SWATH profile were generated from myometrial and decidual samples using 5 and 6 independent patients, respectively. The IDA library was used to identify peptide ions that were present in SWATH ion profiles. Proteins were identified and quantified by comparing SWATH-generated peptide ion profiles for each individual sample against the IDA library (PeakView). IDA of mass spectra from all individual samples was initially performed and with a false discovery rate (FRD) of $1 \%$ identified 678 and 569 total proteins in decidua and myometrium samples, respectively (Supplementary Tables 1 and 2, see section on supplementary materials given at the end of this article). The quantification of all proteins identified for each tissue was performed in all individual samples using SWATH MS/MS. The variation in the relative abundance of proteins between controls (i.e. cells treated with TNF only) and treatment (cells co-treated with TNF and gallic acid) was established by comparison with the SWATH profile against the IDA library and presented as volcano plots (Fig. 10A and C).

In myometrial and decidual cells, a total of 47 and 62 statistically significant protein identifications (FDR $1 \%$, and $P<0.05$ ) in the relative expression of proteins in treatment compared with control were identified, respectively (Tables 1 and 2). Proteins that were significantly different in gallic acid treated samples 

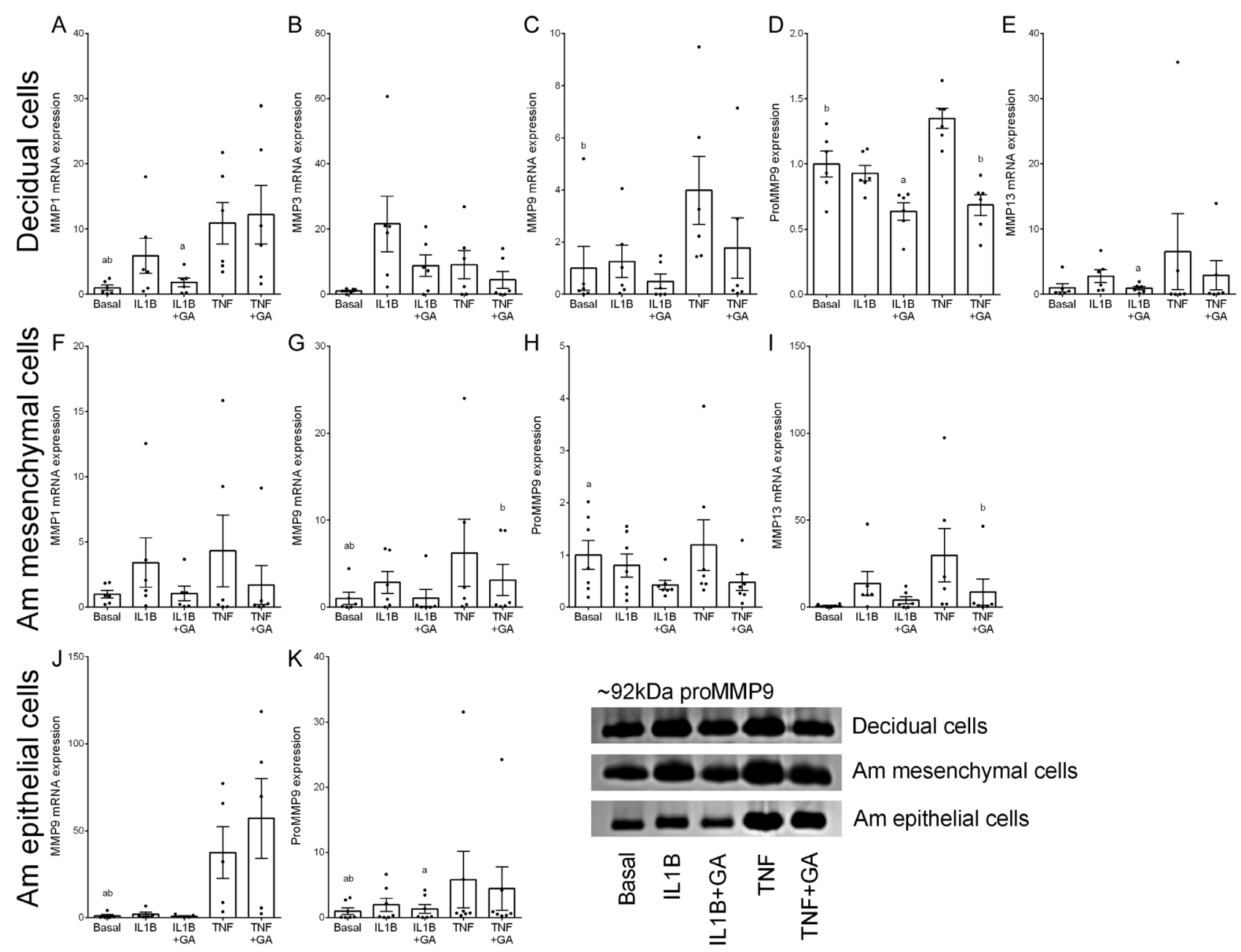

Figure 7 Effect of gallic acid on IL1B- and TNF-induced MMP expression and activity in human primary decidual cells and amnion cells. Human primary decidual (A, B, C, D and E), amnion mesenchymal (F, G, H and I) and amnion epithelial $(\mathrm{J}$ and $\mathrm{K})$ cells were incubated in $1 \mathrm{ng} / \mathrm{mL}$ IL1B or $10 \mathrm{ng} / \mathrm{mL}$ TNF, with or without $1100 \mu \mathrm{M}$ gallic acid (GA) for $20 \mathrm{~h}$ ( $n=6$ patients). (A and F) MMP1, (B) MMP3, (C, G and J) MMP9 and (E and I) MMP13 mRNA expression was analysed by qRT-PCR. (D, H and K) ProMMP9 expression in the incubation media was assessed by gelatin zymography. Representative gel image from one patient/tissue is also shown. For all graphs, each data point represents an individual patient and the bars represent the mean \pm S.E.M. ${ }^{a} P \leq 0.05$ vs IL1B; ${ }^{b} P \leq 0.05$ Vs TNF; repeated measures one-way ANOVA.

compared with controls were subjected to ontology and pathway analysis using IPA (Fig. 10B and D).

In the myometrial cells, the significantly different proteins were associated with signalling pathways associated with 'Dermatological Diseases and Conditions, Inflammatory Disease, Organismal Injury and Abnormalities'. Significantly different molecules in these networks include ACTG1, ANXA5, CNN1, COL1A1, COL1A2, COL3A1, COL6A1, COL6A3, DBNL, EEF1B2, MSN, P4HB, PALLD, PDIA3, PDIA6, PDLIM4, SERPINH1, TPM1, TPM2, and TXNRD1. The full list of significantly different protein identifications in myometrial cells is described in Table 1 . In the decidual cells, the significantly different proteins were associated with signalling pathways associated with 'Gene Expression, Protein Synthesis, RNA Damage and Repair'. Molecules in these networks include AARS1,
ACO2, ACTR3, ANP32A, DFFA, EIF2S1, HNRNPA2B1, HP1BP3, LETM1, NCL, PA2G4, RAB11A, RAD23B, RPL24, RPL3, RPL30, RPL7A, RPS2, and RPS5. The full list of significantly different protein identifications in decidual cells is described in Table 2.

\section{Discussion}

This study is the first to report anti-inflammatory and antilabour properties of gallic acid in cytokine-stimulated gestational tissues in vitro. The data presented in this study found that, in cells isolated from human myometrium and foetal membranes (decidua and amnion mesenchymal cells), gallic acid treatment attenuated TNF-induced mRNA expression and secretion of proinflammatory cytokines and chemokines. In myometrium and decidua, gallic acid treatment attenuated PTGS2 mRNA 

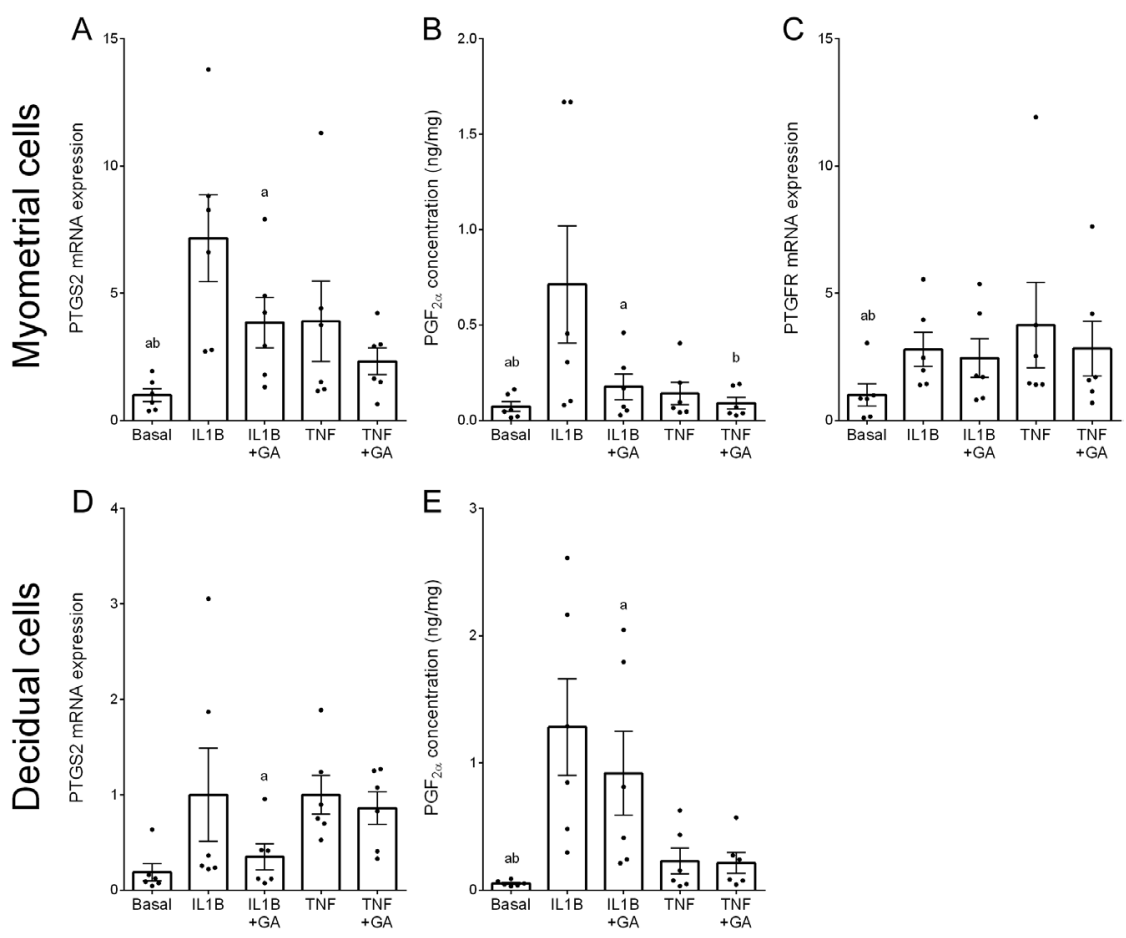

Figure 8 Effect of gallic acid on IL1B- and TNF-induced COX-2-prostaglandin pathway proteins in human primary myometrial and decidual cells. Human primary (A, B and C) myometrial and ( $\mathrm{D}$ and $\mathrm{E})$ decidual cells were incubated in $1 \mathrm{ng} / \mathrm{mL}$ IL1B or $10 \mathrm{ng} / \mathrm{mL}$ TNF, with or without $100 \mu \mathrm{M}$ gallic acid (GA) for $20 \mathrm{~h}$ ( $n=6$ patients). (A and D) PTGS2 and (C) PTGFR mRNA expression and (B and E) PGF concentrations in the incubation media were analysed by qRT-PCR and ELISA, respectively. For all graphs, each data point represents an individual patient and the bars represent the mean \pm S.E.M. ${ }^{\text {a }} P \leq 0.05$ vs IL $1 B ;{ }^{b} P \leq 0.05$ vs TNF; repeated measures one-way ANOVA. expression and PGF release and subsequently inhibited collagen gel contraction induced by TNF in myometrial cells. In cells derived from foetal membranes (decidua, amnion mesenchymal and amnion epithelial), gallic acid reduced MMP expression and activity. Using a
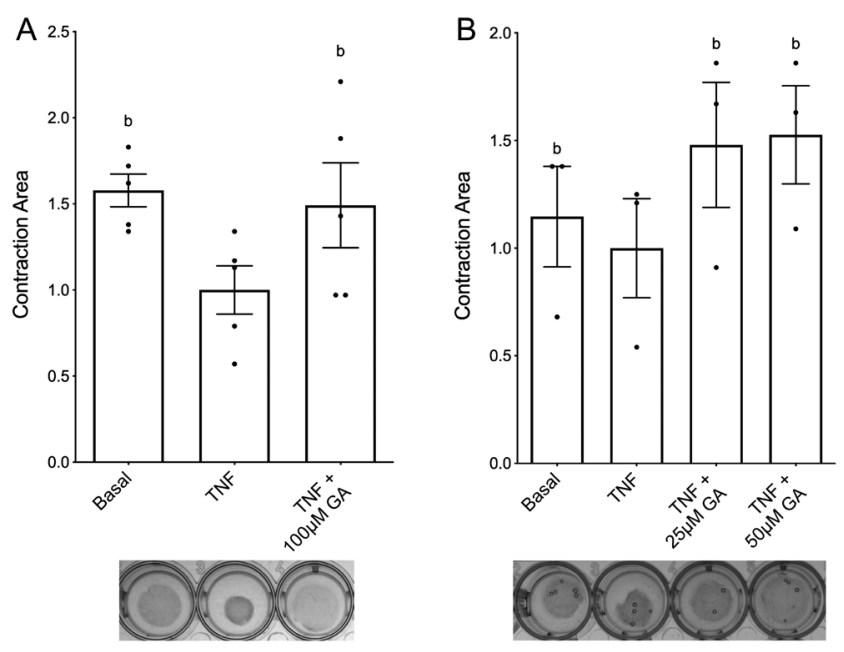

Figure 9 Effect of gallic acid on TNF-induced human primary myometrial cell contraction. Cell contraction assays were performed using 3D collagen gels embedded with human primary myometrial cells and incubated in $10 \mathrm{ng} / \mathrm{mL}$ TNF, with or without (A) $100 \mu \mathrm{M}$ gallic acid (GA) ( $n=5$ patients) or (B) $25 \mu \mathrm{M}$ or $50 \mu \mathrm{M}$ GA $(n=3$ patients) for $50 \mathrm{~h}$. The area of the gel was determined using Chemidoc MP. Representative gel contraction image from one patient is also shown. For all graphs, each data point represents an individual patient, and the bars represent the mean \pm S.E.M. ${ }^{\text {a }} P \leq 0.05$ vs IL1B; ${ }^{\mathrm{b}} P \leq 0.05$ vs TNF; repeated measures one-way ANOVA. global proteomic approach, gallic acid may differentially regulate proteins associated with collagen synthesis, cell contractility and protein synthesis in myometrial and decidual cells.

Pregnancies that culminate in spontaneous preterm birth exhibit abnormal and heightened inflammatory profiles (Wenstrom et al. 1998, Kim et al. 2013). Often triggered by an initial proinflammatory insult, the activated maternal immune system produces proinflammatory cytokines, such as IL1B and TNF, to allow immune infiltration of the gestational tissues and continued production of proinflammatory cytokines and chemokines to generate a positive feedback loop of inflammation (Lappas et al. 2006, Lappas 2017). This proinflammatory cycle then stimulates the production of prostaglandins to activate myometrial contractions (Erkinheimo et al. 2000, Rauk \& Chiao 2000) as well as increases the expression of foetal membrane weakening enzymes, such as MMP9 (Kumar et al. 2006). Using cells derived from human myometrium and foetal membranes (decidua and amnion mesenchyme), we determined the effect of gallic acid on either IL1B or TNF-induced mRNA expression and protein secretion of proinflammatory cytokines and chemokines. We found that gallic acid suppressed the expression and secretion of proinflammatory cytokines and chemokines in all three cell types. IL1B is known to propagate inflammation by stimulating the MyD88 pathway (Lappas 2017), while TNF acts through TRADD signalling (Lim et al. 2017b). Interestingly, gallic acid exerted differential effects in response to IL1B- or TNF-induced inflammation and may, therefore, exert stimuli-specific effects. Gallic acid 

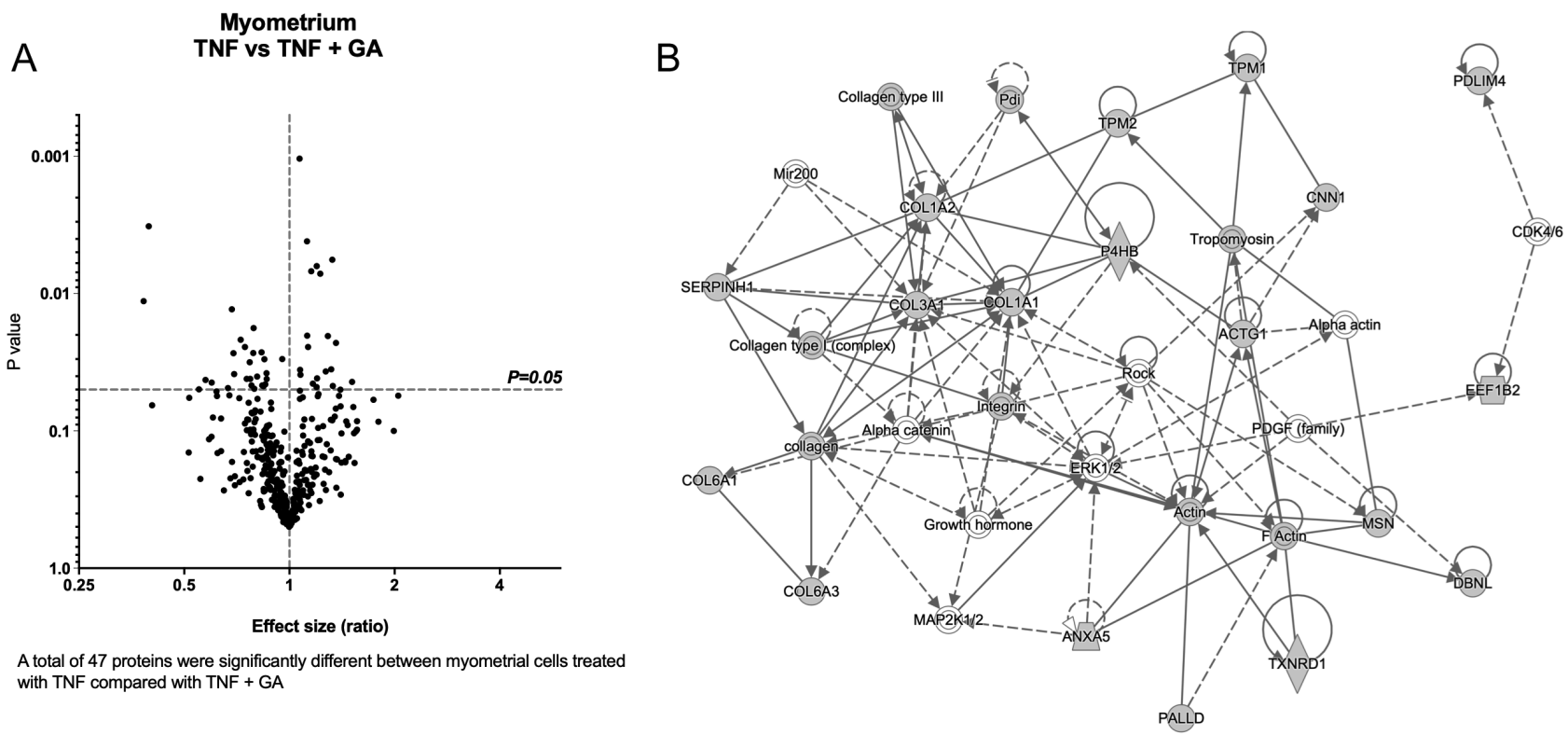
with TNF compared with TNF + GA

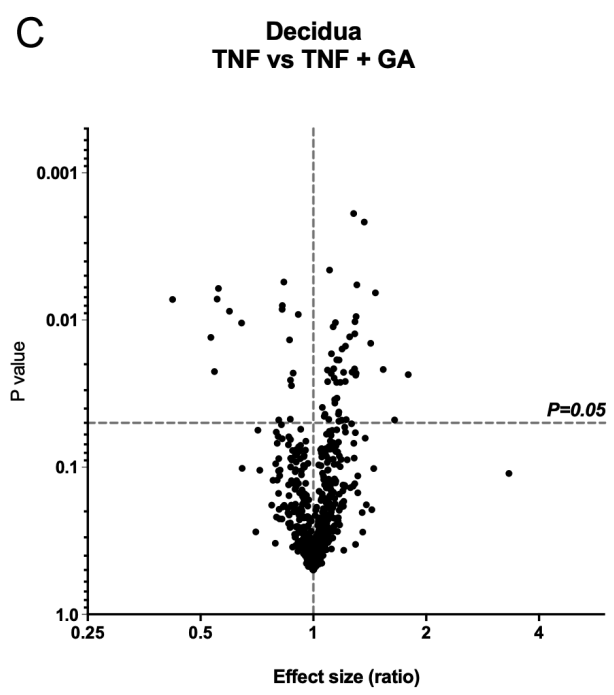

A total of 62 proteins were significantly different between decidua cells treated with TNF compared with TNF + GA

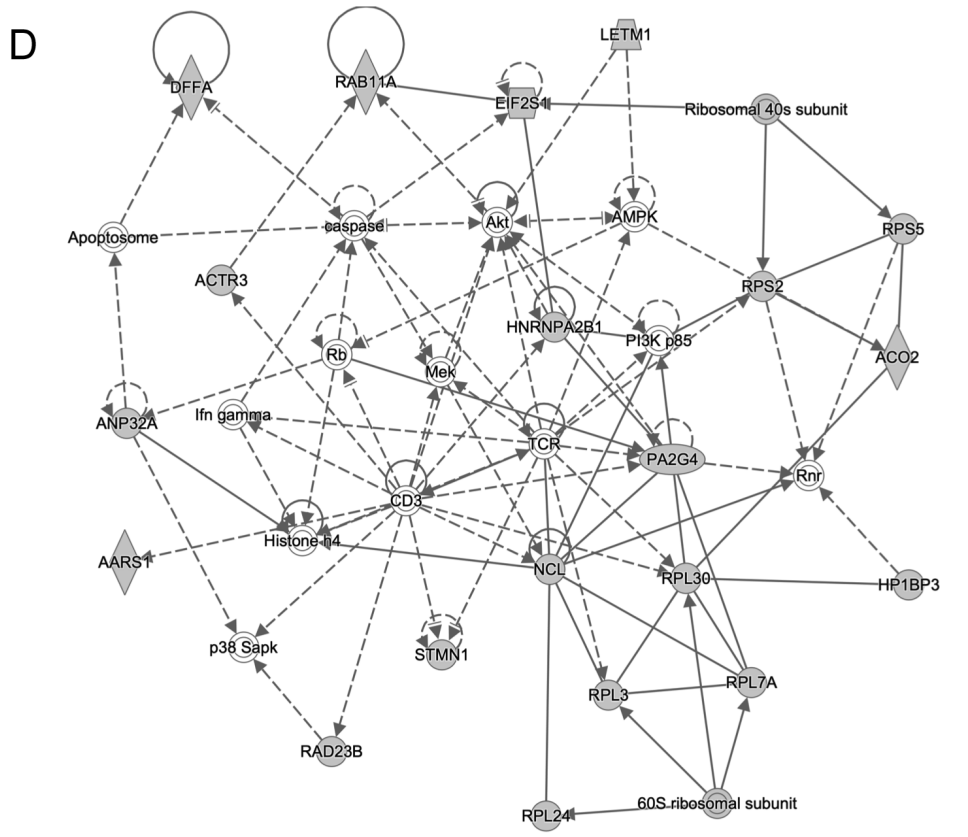

Figure 10 Effect of gallic acid on global protein profile of primary myometrial and decidual cells. Human primary (A and B) myometrial and (C and D) decidual cells were incubated in $10 \mathrm{ng} / \mathrm{mL}$ TNF, with or without $100 \mu \mathrm{M}$ gallic acid (GA) for $20 \mathrm{~h}$ ( $n=5-6$ patients). Proteins were extracted and processed for SWATH and IDA analysis. In each volcano plot (A and C), the horizontal axis represents the fold change and the vertical axis, the $P$ value, where the horizontal dotted line indicates $P=0.05$. Each point represents a protein, with those on the right above the dotted line indicating upregulated proteins and those on the left indicating downregulated proteins. In each signalling network (B and D), the network represents the differentially expressed proteins associated with: (B) Dermatological Diseases and Conditions, Inflammatory Disease, Organismal Injury and Abnormalities, and (D) Gene Expression, Protein Synthesis, RNA Damage and Repair. In each network, the proteins are displayed as nodes and the relationships between the nodes as lines.

may also act in a cell-specific manner; for example, gallic acid significantly suppressed cytokine and chemokine mRNA expression and secretion in myometrial and decidual cells but exerted a weaker effect in amnion mesenchymal cells. Higher doses with longer incubation times of gallic acid treatment may be required to account for these differential effects. Nevertheless, our data demonstrate that gallic acid exerts suppressive effects on inflammation-induced proinflammatory cytokines and chemokines in myometrial, decidual and amnion mesenchymal cells in vitro.

Myometrial activation is mediated through the expression of prostaglandins, such as $\mathrm{PGF}_{2 \alpha}$ (Harper \& Skarnes 1972, Ruttner et al. 2002), and their associated 
Table 1 List of proteins significantly upregulated and downregulated by gallic acid treatment in primary human myometrial cells.

\begin{tabular}{|c|c|c|c|c|}
\hline ID & Gene symbol & Gene name & $\begin{array}{c}\text { Fold } \\
\text { change }\end{array}$ & $\begin{array}{c}\text { Expr } \\
P \text {-value }\end{array}$ \\
\hline \multicolumn{5}{|l|}{ Upregulated } \\
\hline P40925 & MDH1 & malate dehydrogenase 1 & 0.596 & 0.044 \\
\hline P18085 & ARF4 & ADP ribosylation factor 4 & 0.442 & 0.023 \\
\hline P06454 & PTMA & prothymosin alpha & 0.412 & 0.047 \\
\hline Q15084 & PDIA6 & protein disulfide isomerase family A member 6 & 0.408 & 0.006 \\
\hline P46782 & RPS5 & ribosomal protein S5 & 0.398 & 0.036 \\
\hline P39656 & DDOST & $\begin{array}{l}\text { dolichyl-diphosphooligosaccharide--protein glycosyltransferase non-catalytic } \\
\text { subunit }\end{array}$ & 0.365 & 0.020 \\
\hline Q16881 & TXNRD1 & thioredoxin reductase 1 & 0.345 & 0.037 \\
\hline P24534 & EEF1B2 & eukaryotic translation elongation factor 1 beta 2 & 0.293 & 0.007 \\
\hline O00299 & CLIC1 & chloride intracellular channel 1 & 0.264 & 0.041 \\
\hline P29401 & TKT & transketolase & 0.259 & 0.006 \\
\hline Q92945 & KHSRP & KH-type splicing regulatory protein & 0.258 & 0.048 \\
\hline P08758 & ANXA5 & annexin A5 & 0.223 & 0.045 \\
\hline P14314 & PRKCSH & protein kinase $\mathrm{C}$ substrate $80 \mathrm{~K}-\mathrm{H}$ & 0.207 & 0.007 \\
\hline Q8WX93 & PALLD & palladin, cytoskeletal associated protein & 0.178 & 0.025 \\
\hline P07195 & LDHB & lactate dehydrogenase B & 0.168 & 0.020 \\
\hline P07237 & $\mathrm{P} 4 \mathrm{HB}$ & prolyl 4-hydroxylase subunit beta & 0.167 & 0.004 \\
\hline P10809 & HSPD1 & heat shock protein family D (Hsp60) member 1 & 0.104 & 0.039 \\
\hline P61981 & YWHAG & tyrosine 3-monooxygenase/tryptophan 5-monooxygenase activation protein gamma & 0.102 & 0.036 \\
\hline P30101 & PDIA3 & protein disulfide isomerase family A member 3 & 0.097 & 0.001 \\
\hline \multicolumn{5}{|c|}{ Downregulated } \\
\hline P02461 & COL3A1 & collagen type III alpha 1 chain & -2.712 & 0.034 \\
\hline P08123 & COL1A2 & collagen type I alpha 2 chain & -1.385 & 0.011 \\
\hline P02452 & COL1A1 & collagen type I alpha 1 chain & -1.338 & 0.003 \\
\hline P51911 & CNN1 & calponin 1 & -0.859 & 0.050 \\
\hline P50454 & SERPINH1 & serpin family $\mathrm{H}$ member 1 & -0.797 & 0.043 \\
\hline P49411 & TUFM & Tu translation elongation factor, mitochondrial & -0.738 & 0.045 \\
\hline Q9NZN4 & EHD2 & EH domain containing 2 & -0.584 & 0.049 \\
\hline P07951 & TPM2 & tropomyosin 2 & -0.546 & 0.013 \\
\hline O43390 & HNRNPR & heterogeneous nuclear ribonucleoprotein $\mathrm{R}$ & -0.533 & 0.027 \\
\hline Q9UJU6 & DBNL & drebrin like & -0.524 & 0.039 \\
\hline P12109 & COL6A1 & collagen type $\mathrm{VI}$ alpha 1 chain & -0.463 & 0.022 \\
\hline P30050 & RPL12 & ribosomal protein L12 & -0.422 & 0.025 \\
\hline P12111 & COL6A3 & collagen type VI alpha 3 chain & -0.406 & 0.042 \\
\hline P35613 & BSG & basigin (Ok blood group) & -0.378 & 0.032 \\
\hline P50479 & PDLIM4 & PDZ and LIM domain 4 & -0.372 & 0.042 \\
\hline P05556 & ITGB1 & integrin subunit beta 1 & -0.360 & 0.047 \\
\hline P18669 & PGAM1 & phosphoglycerate mutase 1 & -0.343 & 0.027 \\
\hline P61254 & RPL26 & ribosomal protein L26 & -0.340 & 0.018 \\
\hline P17096 & HMGA1 & high mobility group AT-hook 1 & -0.333 & 0.049 \\
\hline P05976 & MYL1 & myosin light chain 1 & -0.307 & 0.040 \\
\hline Q03252 & LMNB2 & lamin B2 & -0.264 & 0.027 \\
\hline Q32P28 & $\mathrm{P} 3 \mathrm{H} 1$ & prolyl 3-hydroxylase 1 & -0.258 & 0.047 \\
\hline P63261 & ACTG1 & actin gamma 1 & -0.246 & 0.047 \\
\hline P09493 & TPM1 & tropomyosin 1 & -0.238 & 0.030 \\
\hline P18124 & RPL7 & ribosomal protein $\mathrm{L} 7$ & -0.229 & 0.046 \\
\hline P16401 & $\mathrm{H} 1-5$ & H1.5 linker histone, cluster member & -0.218 & 0.038 \\
\hline P05787 & KRT8 & keratin 8 & -0.215 & 0.042 \\
\hline P26038 & MSN & moesin & -0.068 & 0.030 \\
\hline
\end{tabular}

signalling pathway proteins such as PTGS2 (Slater et al. 1999) and PTGFR (Senior et al. 1993). Animal studies have demonstrated that $\mathrm{PGF}_{2 \alpha}$ treatment of pregnant mice induces early labour and abortion (Shaw 1983, Sugimoto et al. 1997), while PTGFR knockout models delay parturition (Harper \& Skarnes 1972). Further to this, elevated expression of these prostaglandin pathway proteins in the myometrium have been positively correlated with spontaneous preterm labour
(Olson 2003, Astle et al. 2007, Phillips et al. 2011). The decidua is also a source of prostaglandins, with its synthesis increasing during labour (Skinner \& Challis 1985). Using human myometrial and decidual cells, we investigated the effect of gallic acid on inflammationinduced expression of contraction-associated proteins and prostaglandins. Gallic acid reduced inflammationinduced PTGS2 mRNA expression and secretion of $\mathrm{PGF}_{2 \alpha}$. In myometrial and decidual cells, gallic acid 
Table 2 List of proteins significantly upregulated and downregulated by gallic acid treatment in primary human decidual cells.

\begin{tabular}{|c|c|c|c|c|}
\hline ID & Gene symbol & Gene name & Fold change & Expr $\boldsymbol{P}$-value \\
\hline \multicolumn{5}{|l|}{ Upregulated } \\
\hline P16949 & STMN1 & stathmin 1 & 0.842 & 0.024 \\
\hline P07910 & HNRNPC & heterogeneous nuclear ribonucleoprotein $\mathrm{C}$ & 0.720 & 0.048 \\
\hline Q9UBS4 & DNAJB11 & Dnal heat shock protein family (Hsp40) member B11 & 0.619 & 0.022 \\
\hline P07305 & $\mathrm{H} 1-0$ & $\mathrm{H} 1.0$ linker histone & 0.550 & 0.007 \\
\hline Q99729 & HNRNPAB & heterogeneous nuclear ribonucleoprotein $\mathrm{A} / \mathrm{B}$ & 0.509 & 0.014 \\
\hline P62491 & RAB11A & RAB11A, member RAS oncogene family & 0.450 & 0.002 \\
\hline P05106 & ITGB3 & integrin subunit beta 3 & 0.385 & 0.006 \\
\hline Q14624 & ITIH4 & inter-alpha-trypsin inhibitor heavy chain 4 & 0.379 & 0.023 \\
\hline P09429 & HMGB1 & high mobility group box 1 & 0.378 & 0.009 \\
\hline O00273 & DFFA & DNA fragmentation factor subunit alpha & 0.375 & 0.024 \\
\hline P13647 & KRT5 & keratin 5 & 0.369 & 0.010 \\
\hline Q99798 & ACO2 & aconitase 2 & 0.367 & 0.012 \\
\hline Q9UHB6 & LIMA1 & LIM domain and actin binding 1 & 0.365 & 0.022 \\
\hline Q99733 & NAP1L4 & nucleosome assembly protein 1 like 4 & 0.357 & 0.002 \\
\hline Q14103 & HNRNPD & heterogeneous nuclear ribonucleoprotein D & 0.343 & 0.023 \\
\hline Q14008 & CKAP5 & cytoskeleton associated protein 5 & 0.322 & 0.013 \\
\hline P22626 & HNRNPA2B1 & heterogeneous nuclear ribonucleoprotein A2/B1 & 0.292 & 0.048 \\
\hline P01889 & HLA-B & major histocompatibility complex, class I, B & 0.285 & 0.015 \\
\hline P11413 & G6PD & glucose-6-phosphate dehydrogenase & 0.284 & 0.026 \\
\hline Q92896 & GLG1 & golgi glycoprotein 1 & 0.268 & 0.023 \\
\hline Q9UQ80 & PA2G4 & proliferation-associated 2G4 & 0.255 & 0.016 \\
\hline P38117 & ETFB & electron transfer flavoprotein subunit beta & 0.252 & 0.048 \\
\hline P39023 & RPL3 & ribosomal protein L3 & 0.240 & 0.027 \\
\hline Q5SSJ5 & HP1BP3 & heterochromatin protein 1 binding protein 3 & 0.228 & 0.019 \\
\hline P62888 & RPL30 & ribosomal protein L30 & 0.225 & 0.042 \\
\hline P46782 & RPS5 & ribosomal protein S5 & 0.225 & 0.049 \\
\hline P54727 & RAD23B & RAD23 homolog B, nucleotide excision repair protein & 0.222 & 0.044 \\
\hline Q92973 & TNPO1 & transportin 1 & 0.209 & 0.034 \\
\hline P49327 & FASN & fatty acid synthase & 0.207 & 0.019 \\
\hline P39687 & ANP32A & acidic nuclear phosphoprotein 32 family member $A$ & 0.206 & 0.027 \\
\hline O95782 & AP2A1 & adaptor related protein complex 2 subunit alpha 1 & 0.195 & 0.010 \\
\hline P19338 & $\mathrm{NCL}$ & nucleolin & 0.191 & 0.037 \\
\hline P49411 & TUFM & Tu translation elongation factor, mitochondrial & 0.189 & 0.035 \\
\hline P05198 & EIF2S1 & eukaryotic translation initiation factor 2 subunit alpha & 0.185 & 0.025 \\
\hline P02545 & LMNA & $\operatorname{lamin} \mathrm{A} / \mathrm{C}$ & 0.181 & 0.021 \\
\hline P62424 & RPL7A & ribosomal protein $\mathrm{L} 7 \mathrm{a}$ & 0.176 & 0.011 \\
\hline PODMEO & SETSIP & SET like protein & 0.160 & 0.017 \\
\hline Q15293 & RCN1 & reticulocalbin 1 & 0.158 & 0.023 \\
\hline P13798 & APEH & acylaminoacyl-peptide hydrolase & 0.144 & 0.005 \\
\hline P52907 & CAPZA1 & capping actin protein of muscle Z-line subunit alpha 1 & 0.138 & 0.047 \\
\hline P61158 & ACTR3 & actin related protein 3 & 0.127 & 0.026 \\
\hline P23588 & EIF4B & eukaryotic translation initiation factor 4B & 0.125 & 0.022 \\
\hline P15880 & RPS2 & ribosomal protein S2 & 0.103 & 0.044 \\
\hline Q99426 & TBCB & tubulin folding cofactor B & 0.097 & 0.045 \\
\hline Q8NC51 & SERBP1 & SERPINE1 mRNA binding protein 1 & 0.080 & 0.039 \\
\hline \multicolumn{5}{|c|}{ Downregulated } \\
\hline P02452 & COL1A1 & collagen type I alpha 1 chain & -1.248 & 0.007 \\
\hline P05120 & SERPINB2 & serpin family B member 2 & -0.909 & 0.013 \\
\hline Q02790 & FKBP4 & FKBP prolyl isomerase 4 & -0.876 & 0.022 \\
\hline Q86Y46 & KRT73 & keratin 73 & -0.852 & 0.007 \\
\hline P08123 & COL1A2 & collagen type I alpha 2 chain & -0.841 & 0.006 \\
\hline P02461 & COL3A1 & collagen type III alpha 1 chain & -0.743 & 0.009 \\
\hline P12109 & COL6A1 & collagen type $\mathrm{VI}$ alpha 1 chain & -0.637 & 0.011 \\
\hline P49588 & AARS1 & alanyl-tRNA synthetase 1 & -0.306 & 0.048 \\
\hline P05362 & ICAM1 & intercellular adhesion molecule 1 & -0.276 & 0.008 \\
\hline Q01813 & PFKP & phosphofructokinase, platelet & -0.275 & 0.008 \\
\hline O15460 & $\mathrm{P} 4 \mathrm{HA} 2$ & prolyl 4-hydroxylase subunit alpha 2 & -0.261 & 0.006 \\
\hline P83731 & RPL24 & ribosomal protein L24 & -0.210 & 0.014 \\
\hline Q8N1G4 & LRRC47 & leucine rich repeat containing 47 & -0.204 & 0.047 \\
\hline Q96AY3 & FKBP10 & FKBP prolyl isomerase 10 & -0.203 & 0.026 \\
\hline O95202 & LETM1 & leucine zipper and EF-hand containing transmembrane protein 1 & -0.194 & 0.028 \\
\hline P04406 & GAPDH & glyceraldehyde-3-phosphate dehydrogenase & -0.179 & 0.023 \\
\hline Q9Y230 & RUVBL2 & RuvB like AAA ATPase 2 & -0.133 & 0.009 \\
\hline
\end{tabular}


exerted differential effects in response to TNF and IL1B; in both cell types, gallic acid reduced IL1B-induced PTGS2 mRNA expression and PGF $_{2 \alpha}$ secretion, but only in myometrial cells did gallic acid suppress TNFinduced $\mathrm{PGF}_{2 \alpha}$ secretion. It is possible that different doses and incubation times are also required to affect distinct stages of prostaglandin signalling.

We next investigated the effect of gallic acid on myometrial cell contractility through the use of a collagen gel assay embedded with primary human myometrial cells. Gallic acid treatment was found to block TNF-induced shrinkage of the collagen gel, suggesting gallic acid was able to prevent myometrial cell contractility. A previous study found gallic acid was able to suppress F-actin formation and myosin light chain phosphorylation in TGF- $\beta 1$-stimulated collagen gel contraction (Hsieh et al. 2016). Together, these data suggest gallic acid likely may act directly on downstream mediators involved in cell contraction mediated by TNF. That gallic acid can mitigate inflammation-induced prostaglandin synthesis in both myometrial and decidual cells, as well as suppress myometrial cell contractility, suggests that it may be a potential tocolytic for the prevention of preterm labour.

Preterm premature rupture of membranes (pPROM) occurs through the weakening of the foetal membranes (Lannon et al. 2014). Proinflammatory cytokines are known to regulate the expression and activity of MMPs for the breakdown and digestion of the extracellular matrix (Kumar et al. 2006). To determine the effect of gallic acid on the MMPs, we stimulated cells derived from the foetal membranes (decidua, amnion mesenchyme and amnion epithelium) with IL1B and TNF. We found that gallic acid differentially regulated mRNA expression of MMP1, MMP9 and MMP13 in the three cell types. Furthermore, gallic acid inhibited expression of pro-MMP9 in the decidua and amnion epithelium. MMP1, MMP9 and MMP13 are present in amniotic fluid and implicated to play a role in foetal membrane weakening (Athayde et al. 1998, Maymon et al. 2000). In particular, MMP9 protein expression is demonstrated to increase in foetal membranes during and after labour, compared with before labour (Tsatas et al. 1999). The finding that gallic acid can regulate MMP mRNA expression, and especially reduce MMP9 expression, in cells derived from the foetal membranes suggest that gallic acid may be able to prevent foetal membrane weakening associated with pPROM.

A global proteomic approach was used to identify the mechanistic pathways through which gallic acid may be acting in myometrial and decidual cells. Interestingly, for both myometrial and decidual cells, gallic acid was found to alter the regulation of proteins involved in collagen synthesis and cellular contractility, as well as protein synthesis and nuclear integrity. Notably, in myometrial cells, gallic acid co-treatment was found to downregulate proteins associated with cell contractility and movement. These include myosin light chain 1 and tropomyosins 1 and 2, all of which are thought to directly bind with actin to induce cellular contractility (Marston \& El-Mezgueldi 2008, Nguyen-Ngo \& Lappas 2020). Gallic acid was also found to significantly downregulate collagen proteins, including type 1, type 3 and type 6 collagens in both myometrial and decidual cells. Fibrillar collagens type I and III are necessary strength-providing components of the extracellular matrix (ECM) (Kisalus et al. 1987, Malak et al. 1993, Mylona et al. 1995), where extensive remodelling of the myometrium and the foetal membranes leads to increasing concentration with advancing gestation (Puistola et al. 1993). In particular, ECM proteins, including collagens, have been found to increase in labouring rat myometrium to induce myometrial contractions (Shynlova et al. 2004, 2009) as well as in human preterm premature rupture of membranes (Meirowitz et al. 2002) and preterm labour (Shankar et al. 2010). Together, these findings suggest that gallic acid may influence tissue remodelling in both myometrium and foetal membranes. In conjunction with our functional collagen gel contractility data, gallic acid may also directly target downstream mechanisms to reduce TNF-induced myometrial cell contractility in collagen gels.

Gallic acid also downregulated the adhesion molecule ICAM1, which is known to play a role in leukocyte infiltration of the myometrium and foetal membranes during labour (Thomson et al. 1999, Ledingham et al. 2001). Supporting this, our study found that gallic acid treatment significantly reduced soluble ICAM1 secretion in the incubation media of TNF-stimulated decidual cells (Supplementary Fig. 1). Together, these data suggest that gallic acid may limit leukocyte infiltration into the decidua to block the production of proinflammatory cytokines and chemokines and ultimately prevent the proinflammatory cycle associated with preterm birth.

Other changes induced by gallic acid treatment include differential expression of proteins involved in protein synthesis and nuclear integrity in both myometrial and decidual cells.

In myometrial cells, proteins associated with chromatin and nuclear structure, and ribosomal components were downregulated, while proteins involved in protein translation and posttranslational modifications were upregulated. In decidual cells, proteins associated with eukaryotic translation factors, ribosomal components and posttranslational modifications were upregulated. We have previously demonstrated dysregulated expression of molecules involved in protein synthesis in myometrium and foetal membranes from labouring women compared with non-labouring women, which was associated with the production of proinflammatory and pro-labour mediators (Liong \& Lappas 2018). Similarly, preterm infected or ruptured membranes also exhibited dysregulated expression of protein synthesis molecules compared with non-infected or 
intact membranes (Liong \& Lappas 2018). These data suggest that gallic acid may be able to reverse labourinduced changes in protein synthesis machinery to reduce the inflammatory response in the myometrium and foetal membranes. Notably, in decidual cells, gallic acid upregulated eukaryotic translation initiation factor (EIF)4B, which acts as a cofactor for ElF4 subunit A (Sen et al. 2016). Aside from regulating protein synthesis, EIF4 is also associated with cell cycle progression and apoptosis resistance (Ruggero et al. 2004, Wendel et al. 2004, Holcik \& Sonenberg 2005, Proud 2015, Zhan et al. 2015). Gallic acid was also found to upregulate proteins associated with nucleic acid structure and integrity, as well as nuclear membrane structure and assembly in decidual cells, indicating that gallic acid may exert a protective effect against inflammationinduced damage of nucleic material. Altogether, this may suggest that gallic acid programs cells for survival in proinflammatory environments, which holds important implications for the foetal membranes, where apoptosis and cell death are a mechanism for the rupture of the membranes (Fortunato et al. 2000, Reti et al. 2007). These findings suggest that gallic acid may act on a number of signalling targets to prevent myometrial contractions and foetal membrane rupture associated with preterm birth.

Cervical ripening and softening is the third component of the common pathway of parturition and involves MMP-induced remodelling and degradation to allow the passage of the fetus through the cervical canal (Vink \& Myers 2018). Inflammation is also thought to contribute to this process in both preterm and term labouring women (Dobyns et al. 2015, Dubicke et al. 2016, Yellon 2017). Whether gallic acid can also prevent inflammation associated with cervical ripening is an avenue of further research.

This study is not without limitations. Spontaneous preterm birth is a complex disease where other infectious agents, such as bacterial FSL-1 or viral poly(I:C), may also contribute to the pathophysiology of preterm birth by triggering distinct pathways to the proinflammatory cytokines (Lim et al. 2017a). Thus, the findings presented here should be interpreted with some caution. Despite this, the study's strengths lie in the use of four distinct primary human cell lines derived from the critical tissues involved in preterm birth, including the myometrium and the foetal membranes (decidua, amnion mesenchyme and amnion epithelium). In addition, the effects of gallic acid were measured in response to either IL1B or TNF, each of which induces inflammation through distinct pathways.

The findings in this study warrant future preclinical studies on the safety and efficacy of gallic acid in pregnant animal models. Previous non-pregnant human clinical trials, as well as a pregnant rat study, have found safety in gallic acid supplementation (Booth et al. 2010, Fairus et al. 2018, Ferk et al. 2018). Pregnant rats treated with up to $860 \mathrm{mg} / \mathrm{kg}$ gallic acid (equivalent to $6.8 \mathrm{~g} /$ $\mathrm{mL}$ ) from gd 6 to 20 were deemed healthy, with no adverse effect on maternal or foetal outcomes (Booth et al. 2010). Of note, non-pregnant human clinical trials found that daily supplementation of $450 \mathrm{mg}$ gallic acid equivalent for 60 days was safe for consumption (Fairus et al. 2018). By comparison, our study used a dose of $100 \mu \mathrm{M}$ or $0.17 \mathrm{mg} / \mathrm{mL}$ gallic acid. It is imperative that future preclinical studies identify the safety and efficacy of gallic acid in preventing spontaneous preterm birth using in vivo mouse studies.

Despite impacting 15 million pregnancies every year, current prevention therapeutics for spontaneous preterm birth possess limited effectiveness in some, but not all, subsets of at-risk pregnancies (Beck et al. 2010, Haas et al. 2012). In this study, we assessed the effect of the polyphenol gallic acid on cytokine-stimulated gestational tissues in vitro. We found that gallic acid treatment was able to suppress the production of key mediators involved in myometrial activation and the rupture of foetal membranes, including proinflammatory cytokines, chemokines, prostaglandin pathwayassociated proteins, uterotonics and MMPs. Global proteomic data suggest that gallic acid may differentially regulate proteins associated with collagen synthesis, cell contractility and gene expression in myometrial and decidual cells. Altogether, these data suggest that gallic acid may be a novel therapeutic to prevent myometrial contractions and rupture of membranes associated with spontaneous preterm birth. Additional studies are warranted to determine if gallic acid may be able to prevent preterm birth and improve foetal outcome in an in vivo animal model.

\section{Supplementary materials}

This is linked to the online version of the paper at https://doi. org/10.1530/REP-20-0249.

\section{Declaration of interest}

The authors declare that there is no conflict of interest that could be perceived as prejudicing the impartiality of the research reported.

\section{Funding}

Associate Professor Martha Lappas is supported by a Research Fellowship from the Department of Obstetrics and Gynaecology (University of Melbourne) and a Faculty Fellowship from the University of Melbourne. Dr Carlos Salomon is supported by the Lions Medical Research Foundation and Fondo Nacional de Desarrollo Científico y Tecnológico (FONDECYT 1170809). Caitlyn Nguyen-Ngo is supported by an Australian Government Research Training Program (RTP) Scholarship. This study was supported by grants from the Norman Beischer 
Medical Research Foundation, Austin Medical Research Foundation, the University of Melbourne and the Mercy Research Foundation.

\section{Author contribution statement}

$M L$ designed the study and critically reviewed the manuscript. $\mathrm{C} \mathrm{N-N} \mathrm{conducted} \mathrm{the} \mathrm{experiments,} \mathrm{performed} \mathrm{data} \mathrm{analysis}$ and wrote the initial draft of the manuscript. C S performed mass spectrometry analysis. A L provided technical assistance. J C W critically reviewed the study and the manuscript.

\section{Acknowledgements}

The authors gratefully acknowledge Dr Ratana Lim for her technical assistance; the clinical Research Midwives Gabrielle Pell, Genevieve Christophers and Rachel Murdoch for sample collection; the Obstetrics and Midwifery staff of the Mercy Hospital for Women for their co-operation; and the women who generously donated their tissue samples to the study. The authors acknowledge the assistance of the mass spectrometry facilities at the Centre for Clinical Diagnostics within the UQ Centre for Clinical Research, a National Association of Testing Authorities accredited facility.

\section{References}

Araujo AB, Furlan JM, Salton GD, Schmalfuss T, Rohsig LM, Silla LMR, Passos EP \& Paz AH 2018 Isolation of human mesenchymal stem cells from amnion, chorion, placental decidua and umbilical cord: comparison of four enzymatic protocols. Biotechnology Letters 40 989-998. (https://doi.org/10.1007/s10529-018-2546-z)

Astle S, Newton R, Thornton S, Vatish M \& Slater DM 2007 Expression and regulation of prostaglandin $\mathrm{E}$ synthase isoforms in human myometrium with labour. Molecular Human Reproduction 13 69-75. (https://doi. org/10.1093/molehr/gal093)

Athayde N, Edwin SS, Romero R, Gomez R, Maymon E, Pacora P \& Menon R 1998 A role for matrix metalloproteinase-9 in spontaneous rupture of the fetal membranes. American Journal of Obstetrics and Gynecology 179 1248-1253. (https://doi.org/10.1016/s0002-9378(98)70141-3)

Barr SM, Walker BR, Morton NM \& Norman JE 2011 Pro-inflammatory gene mRNA levels are elevated in subcutaneous but not visceral adipose tissue in obese pregnant women. BJOG 118 1008-1017. (https://doi. org/10.1111/j.1471-0528.2011.03037.x)

Beck S, Wojdyla D, Say L, Betran AP, Merialdi M, Requejo JH, Rubens C, Menon R \& Van Look PF 2010 The worldwide incidence of preterm birth: a systematic review of maternal mortality and morbidity. Bulletin of the World Health Organization 88 31-38. (https://doi.org/10.2471/ BLT.08.062554)

Blencowe H, Cousens S, Oestergaard MZ, Chou D, Moller AB, Narwal R, Adler A, Vera Garcia C, Rohde S, Say L et al. 2012 National, regional, and worldwide estimates of preterm birth rates in the year 2010 with time trends since 1990 for selected countries: a systematic analysis and implications. Lancet 379 2162-2172. (https://doi.org/10.1016/S01406736(12)60820-4)

Booth A, Amen RJ, Scott M \& Greenway FL 2010 Oral dose-ranging developmental toxicity study of an herbal supplement (NT) and gallic acid in rats. Advances in Therapy 27 250-255. (https://doi.org/10.1007/ s12325-010-0021-x)

Catalano PM \& Ehrenberg HM 2006 The short- and long-term implications of maternal obesity on the mother and her offspring. BJOG 113 1126-1133. (https://doi.org/10.1111/j.1471-0528.2006.00989.x)

Chai M, Barker G, Menon R \& Lappas M 2012 Increased oxidative stress in human fetal membranes overlying the cervix from term non-labouring and post labour deliveries. Placenta 33 604-610. (https:// doi.org/10.1016/j.placenta.2012.04.014)

Choi KC, Lee YH, Jung MG, Kwon SH, Kim MJ, Jun WJ, Lee J, Lee JM \& Yoon HG 2009 Gallic acid suppresses lipopolysaccharide-induced nuclear factor-kappaB signaling by preventing RelA acetylation in A549 lung cancer cells. Molecular Cancer Research 7 2011-2021. (https://doi. org/10.1158/1541-7786.MCR-09-0239)

Dobyns AE, Goyal R, Carpenter LG, Freeman TC, Longo LD \& Yellon SM 2015 Macrophage gene expression associated with remodeling of the prepartum rat cervix: microarray and pathway analyses. PLOS ONE 10 e0119782. (https://doi.org/10.1371/journal.pone.0119782)

Dubicke A, Ekman-Ordeberg G, Mazurek P, Miller L \& Yellon SM 2016 Density of stromal cells and macrophages associated with collagen remodeling in the human cervix in preterm and term birth. Reproductive Sciences 23 595-603. (https://doi.org/10.1177/1933719115616497)

Englund-Ogge L, Brantsaeter AL, Sengpiel V, Haugen M, Birgisdottir BE, Myhre R, Meltzer HM \& Jacobsson B 2014 Maternal dietary patterns and preterm delivery: results from large prospective cohort study. BMJ 348 g1446. (https://doi.org/10.1136/bmj.g1446)

Erkinheimo TL, Saukkonen K, Narko K, Jalkanen J, Ylikorkala O \& Ristimaki A 2000 Expression of cyclooxygenase-2 and prostanoid receptors by human myometrium. Journal of Clinical Endocrinology and Metabolism 85 3468-3475. (https://doi.org/10.1210/jcem.85.9.6809)

Fairus S, Leow SS, Mohamed IN, Tan YA, Sundram K \& Sambanthamurthi R 2018 A phase I single-blind clinical trial to evaluate the safety of oil palm phenolics (OPP) supplementation in healthy volunteers. Scientific Reports 8 8217. (https://doi.org/10.1038/s41598-018-26384-7)

Ferk F, Kundi M, Brath H, Szekeres T, Al-Serori H, Misik M, Saiko P, Marculescu R, Wagner KH \& Knasmueller S 2018 Gallic acid improves health-associated biochemical parameters and prevents oxidative damage of DNA in Type 2 diabetes patients: results of a placebocontrolled pilot study. Molecular Nutrition and Food Research 62. (https://doi.org/10.1002/mnfr.201700482)

Flenady V, Hawley G, Stock OM, Kenyon S \& Badawi N 2013 Prophylactic antibiotics for inhibiting preterm labour with intact membranes. Cochrane Database of Systematic Reviews Cd000246. (https://doi. org/10.1002/14651858.CD000246.pub2)

Fortunato SJ, Menon R, Bryant C \& Lombardi SJ 2000 Programmed cell death (apoptosis) as a possible pathway to metalloproteinase activation and fetal membrane degradation in premature rupture of membranes. American Journal of Obstetrics and Gynecology 182 1468-1476. (https://doi.org/10.1067/mob.2000.107330)

Goldenberg RL, Hauth JC \& Andrews WW 2000 Intrauterine infection and preterm delivery. New England Journal of Medicine 342 1500-1507. (https://doi.org/10.1056/NEJM200005183422007)

Haas DM, Caldwell DM, Kirkpatrick P, Mcintosh JJ \& Welton NJ 2012 Tocolytic therapy for preterm delivery: systematic review and network meta-analysis. BMJ 345 e6226. (https://doi.org/10.1136/bmj.e6226)

Hamilton S, Oomomian Y, Stephen G, Shynlova O, Tower CL, Garrod A, Lye SJ \& Jones RL 2012 Macrophages infiltrate the human and rat decidua during term and preterm labor: evidence that decidual inflammation precedes labor. Biology of Reproduction 86 39-39. (https://doi. org/10.1095/biolreprod.111.095505)

Harper MJ \& Skarnes RC 1972 Inhibition of abortion and fetal death produced by endotoxin or prostaglandin F2alpha. Prostaglandins $\mathbf{2}$ 295-309. (https://doi.org/10.1016/s0090-6980(72)80017-0)

Holcik M \& Sonenberg N 2005 Translational control in stress and apoptosis. Nature Reviews: Molecular Cell Biology 6 318-327. (https:// doi.org/10.1038/nrm1618)

Hsiang CY, Hseu YC, Chang YC, Kumar KJ, Ho TY \& Yang HL 2013 Toona sinensis and its major bioactive compound gallic acid inhibit LPS-induced inflammation in nuclear factor-kappaB transgenic mice as evaluated by in vivo bioluminescence imaging. Food Chemistry 136 426-434. (https://doi.org/10.1016/j.foodchem.2012.08.009)

Hsieh SC, Wu CC, Hsu SL, Feng CH \& Yen JH 2016 Gallic acid attenuates TGF-beta1-stimulated collagen gel contraction via suppression of RhoA/ Rho-kinase pathway in hypertrophic scar fibroblasts. Life Sciences 161 19-26. (https://doi.org/10.1016/j.lfs.2016.07.011)

Jayabalan N, Lai A, Nair S, Guanzon D, Scholz-Romero K, Palma C, Mcintyre HD, Lappas M \& Salomon C 2019 Quantitative proteomics by SWATH-MS suggest an association between circulating exosomes and 
maternal metabolic changes in gestational diabetes mellitus. Proteomics 19 e1800164. (https://doi.org/10.1002/pmic.201800164)

Kenyon S, Boulvain M \& Neilson JP 2013 Antibiotics for preterm rupture of membranes. Cochrane Database of Systematic Reviews CD001058. (https://doi.org/10.1002/14651858.CD001058.pub3)

Kim A, Lee ES, Shin JC \& Kim HY 2013 Identification of biomarkers for preterm delivery in mid-trimester amniotic fluid. Placenta 34 873-878. (https://doi.org/10.1016/j.placenta.2013.06.306)

Kisalus LL, Herr JC \& Little CD 1987 Immunolocalization of extracellular matrix proteins and collagen synthesis in first-trimester human decidua. Anatomical Record 218 402-415. (https://doi.org/10.1002/ ar.1092180408)

Kumar D, Fung W, Moore RM, Pandey V, Fox J, Stetzer B, Mansour JM, Mercer BM, Redline RW \& Moore JJ 2006 Proinflammatory cytokines found in amniotic fluid induce collagen remodeling, apoptosis, and biophysical weakening of cultured human fetal membranes. Biology of Reproduction 74 29-34. (https://doi.org/10.1095/ biolreprod.105.045328)

Lannon SM, Vanderhoeven JP, Eschenbach DA, Gravett MG \& Adams Waldorf KM 2014 Synergy and interactions among biological pathways leading to preterm premature rupture of membranes. Reproductive Sciences 21 1215-1227. (https://doi.org/10.1177/1933719114534535)

Lappas M 2017 The IL-1beta signalling pathway and its role in regulating pro-inflammatory and pro-labour mediators in human primary myometrial cells. Reproductive Biology 17 333-340. (https://doi. org/10.1016/j.repbio.2017.09.006)

Lappas M, Yee K, Permezel M \& Rice GE 2006 Lipopolysaccharide and TNF- $\alpha$ activate the nuclear factor kappa B pathway in the human placental JEG-3 cells. Placenta 27 568-575. (https://doi.org/10.1016/j. placenta.2005.06.003)

Ledingham MA, Thomson AJ, Jordan F, Young A, Crawford M \& Norman JE 2001 Cell adhesion molecule expression in the cervix and myometrium during pregnancy and parturition. Obstetrics and Gynecology 97 235-242. (https://doi.org/10.1016/s0029-7844(00)01126-1)

Lee W, Lee SY, Son YJ \& Yun JM 2015 Gallic acid decreases inflammatory cytokine secretion through histone acetyltransferase/histone deacetylase regulation in high glucose-induced human monocytes. Journal of Medicinal Food 18 793-801. (https://doi.org/10.1089/jmf.2014.3342)

Leimert KB, Verstraeten BSE, Messer A, Nemati R, Blackadar K, Fang X, Robertson SA, Chemtob S \& Olson DM 2019 Cooperative effects of sequential PGF2alpha and IL-1beta on IL-6 and COX-2 expression in human myometrial cellsdagger. Biology of Reproduction 100 1370-1385. (https://doi.org/10.1093/biolre/ioz029)

Lim R \& Lappas M 2019 Expression and function of macrophage-inducible C-type lectin (Mincle) in inflammation driven parturition in fetal membranes and myometrium. Clinical and Experimental Immunology 197 95-110. (https://doi.org/10.1111/cei.13281)

Lim R, Barker G \& Lappas M 2013a A novel role for FOXO3 in human labor: increased expression in laboring myometrium, and regulation of proinflammatory and prolabor mediators in pregnant human myometrial cells. Biology of Reproduction 88 156. (https://doi.org/10.1095/ biolreprod.113.108126)

Lim R, Barker G \& Lappas M $2013 b$ SIRT6 is decreased with preterm labor and regulates key terminal effector pathways of human labor in fetal membranes. Biology of Reproduction 88 17. (https://doi.org/10.1095/ biolreprod.112.105163)

Lim R, Barker G, Wall CA \& Lappas M 2013C Dietary phytophenols curcumin, naringenin and apigenin reduce infection-induced inflammatory and contractile pathways in human placenta, foetal membranes and myometrium. Molecular Human Reproduction 19 451-462. (https://doi.org/10.1093/molehr/gat015)

Lim R, Morwood CJ, Barker G \& Lappas M 2014 Effect of silibinin in reducing inflammatory pathways in in vitro and in vivo models of infection-induced preterm birth. PLOS ONE 9 e92505. (https://doi. org/10.1371/journal.pone.0092505)

Lim R, Barker G \& Lappas M 2017a TLR2, TLR3 and TLR5 regulation of proinflammatory and pro-labour mediators in human primary myometrial cells. Journal of Reproductive Immunology 122 28-36. (https://doi. org/10.1016/j.jri.2017.08.004)

Lim R, Barker G \& Lappas M 2017b TRADD, TRAF2, RIP1 and TAK1 are required for TNF-alpha-induced pro-labour mediators in human primary myometrial cells. American Journal of Reproductive Immunology $\mathbf{7 8 .}$ (https://doi.org/10.1111/aji.12664)
Liong S \& Lappas M 2018 Markers of protein synthesis are increased in fetal membranes and myometrium after human labour and delivery. Reproduction, Fertility, and Development 30 313-329. (https://doi. org/10.1071/RD17081)

Malak TM, Ockleford CD, Bell SC, Dalgleish R, Bright N \& Macvicar J 1993 Confocal immunofluorescence localization of collagen types I, III, IV, V and VI and their ultrastructural organization in term human fetal membranes. Placenta 14 385-406. (https://doi.org/10.1016/s01434004(05)80460-6)

Manach C, Scalbert A, Morand C, Remesy C \& Jimenez L 2004 Polyphenols: food sources and bioavailability. American Journal of Clinical Nutrition 79 727-747. (https://doi.org/10.1093/ajcn/79.5.727)

Marston S \& El-Mezgueldi M 2008 Role of tropomyosin in the regulation of contraction in smooth muscle. Advances in Experimental Medicine and Biology 644 110-123. (https://doi.org/10.1007/978-0-387-85766-4_9)

Maymon E, Romero R, Pacora P, Gervasi MT, Bianco K, Ghezzi F \& Yoon BH 2000 Evidence for the participation of interstitial collagenase (matrix metalloproteinase 1) in preterm premature rupture of membranes. American Journal of Obstetrics and Gynecology 183 914-920. (https:// doi.org/10.1067/mob.2000.108879)

Meirowitz NB, Smulian JC, Hahn RA, Zhou P, Shen-Schwarz S, Lambert GH, Gerecke DR \& Gordon MK 2002 Collagen messenger RNA expression in the human amniochorion in premature rupture of membranes. American Journal of Obstetrics and Gynecology 187 1679-1685. (https://doi.org/10.1067/mob.2002.127595)

Moore TA, Ahmad IM \& Zimmerman MC 2018 Oxidative stress and preterm birth: an integrative review. Biological Research for Nursing 20 497-512. (https://doi.org/10.1177/1099800418791028)

Morwood CJ \& Lappas M 2014 The citrus flavone nobiletin reduces pro-inflammatory and pro-labour mediators in fetal membranes and myometrium: implications for preterm birth. PLOS ONE 9 e108390. (https://doi.org/10.1371/journal.pone.0108390)

Mwaniki MK, Atieno M, Lawn JE \& Newton CR 2012 Long-term neurodevelopmental outcomes after intrauterine and neonatal insults: a systematic review. Lancet 379 445-452. (https://doi.org/10.1016/S01406736(11)61577-8)

Myhre R, Brantsaeter AL, Myking S, Eggesbo M, Meltzer HM, Haugen M \& Jacobsson B 2013 Intakes of garlic and dried fruits are associated with lower risk of spontaneous preterm delivery. Journal of Nutrition 143 1100-1108. (https://doi.org/10.3945/jn.112.173229)

Mylona P, Kielty CM, Hoyland JA \& Aplin JD 1995 Expression of type VI collagen mRNAs in human endometrium during the menstrual cycle and first trimester of pregnancy. Journal of Reproduction and Fertility 103 159-167. (https://doi.org/10.1530/jrf.0.1030159)

Nguyen-Ngo C \& Lappas M 2020 Mechanisms of normal labour. Current Opinion in Physiology 13 27-32. (https://doi.org/10.1016/j. cophys.2019.09.008)

Nguyen-Ngo C, Salomon C, Quak S, Lai A, Willcox JC \& Lappas M 2020 Nobiletin exerts anti-diabetic and anti-inflammatory effects in an in vitro human model and in vivo murine model of gestational diabetes. Clinical Science 134 571-592. (https://doi.org/10.1042/CS20191099)

Olson DM 2003 The role of prostaglandins in the initiation of parturition. Best Practice and Research: Clinical Obstetrics and Gynaecology 17 717-730. (https://doi.org/10.1016/s1521-6934(03)00069-5)

Olson DM \& Ammann C 2007 Role of the prostaglandins in labour and prostaglandin receptor inhibitors in the prevention of preterm labour. Frontiers in Bioscience 12 1329-1343. (https://doi.org/10.2741/2151)

Pandurangan AK, Mohebali N, Esa NM, Looi CY, Ismail S \& Saadatdoust Z 2015 Gallic acid suppresses inflammation in dextran sodium sulfate-induced colitis in mice: possible mechanisms. International Immunopharmacology 28 1034-1043. (https://doi.org/10.1016/j. intimp.2015.08.019)

Phillips RJ, Al-Zamil H, Hunt LP, Fortier MA \& Lopez Bernal A 2011 Genes for prostaglandin synthesis, transport and inactivation are differentially expressed in human uterine tissues, and the prostaglandin $\mathrm{F}$ synthase AKR1B1 is induced in myometrial cells by inflammatory cytokines. Molecular Human Reproduction 17 1-13. (https://doi.org/10.1093/ molehr/gaq057)

Proud CG 2015 Mnks, elF4E phosphorylation and cancer. Biochimica et Biophysica Acta 1849 766-773. (https://doi.org/10.1016/j. bbagrm.2014.10.003)

Puistola U, Risteli L, Kauppila A, Knip M \& Risteli J 1993 Markers of type I and type III collagen synthesis in serum as indicators of tissue growth 
during pregnancy. Journal of Clinical Endocrinology and Metabolism 77 178-182. (https://doi.org/10.1210/jcem.77.1.8325940)

Rauk PN \& Chiao JP 2000 Interleukin-1 stimulates human uterine prostaglandin production through induction of cyclooxygenase-2 expression. American Journal of Reproductive Immunology 43 152-159. (https://doi.org/10.1111/j.8755-8920.2000.430304.x)

Reti NG, Lappas M, Riley C, Wlodek ME, Permezel M, Walker S \& Rice GE 2007 Why do membranes rupture at term? Evidence of increased cellular apoptosis in the supracervical fetal membranes. American Journal of Obstetrics and Gynecology 196 484.e1-484.e10. (https://doi. org/10.1016/j.ajog.2007.01.021)

Ruggero D, Montanaro L, Ma L, Xu W, Londei P, Cordon-Cardo C \& Pandolfi PP 2004 The translation factor elF-4E promotes tumor formation and cooperates with c-Myc in lymphomagenesis. Nature Medicine $\mathbf{1 0}$ 484-486. (https://doi.org/10.1038/nm1042)

Ruttner Z, Ivanics T, Slaaf DW, Reneman RS, Toth A \& Ligeti L 2002 In vivo monitoring of intracellular free calcium changes during uterine activation by prostaglandin F(2alpha) and oxytocin. Journal of the Society for Gynecologic Investigation 9 294-298. (https://doi.org/10.1016/s10715576(02)00169-7)

Sen ND, Zhou F, Harris MS, Ingolia NT \& Hinnebusch AG 2016 elF4B stimulates translation of long mRNAs with structured $5^{\prime}$ UTRs and low closed-loop potential but weak dependence on elF4G. PNAS 113 10464-10472. (https://doi.org/10.1073/pnas.1612398113)

Senior J, Marshall K, Sangha R \& Clayton JK 1993 In vitro characterization of prostanoid receptors on human myometrium at term pregnancy. British Journal of Pharmacology 108 501-506. (https://doi. org/10.1111/j.1476-5381.1993.tb12832.x)

Shankar R, Johnson MP, Williamson NA, Cullinane F, Purcell AW, Moses EK \& Brennecke SP 2010 Molecular markers of preterm labor in the choriodecidua. Reproductive Sciences 17 297-310. (https://doi. org/10.1177/1933719109353454)

Shao D, Zhang L, Du S, Yokoyama W, Shi J, Li N \& Wang J 2016 Polyphenolic content and color of seedless and seeded shade dried Chinese raisins. Food Science and Technology Research 22 359-369. (https://doi.org/10.3136/fstr.22.359)

Shaw G 1983 Effect of PGF-2 alpha on uterine activity, and concentrations of 13, 14-dihydro-15-keto-PGF-2 alpha in peripheral plasma during parturition in the tammar wallaby (Macropus eugenii). Journal of Reproduction and Fertility 69 429-436. (https://doi.org/10.1530/ jrf.0.0690429)

Shynlova O, Mitchell JA, Tsampalieros A, Langille BL \& Lye SJ 2004 Progesterone and gravidity differentially regulate expression of extracellular matrix components in the pregnant rat myometrium. Biology of Reproduction 70 986-992. (https://doi.org/10.1095/ biolreprod.103.023648)

Shynlova O, Chow M \& Lye SJ 2009 Expression and organization of basement membranes and focal adhesion proteins in pregnant myometrium is regulated by uterine stretch. Reproductive Sciences $\mathbf{1 6}$ 960-969. (https://doi.org/10.1177/1933719109338220)

Skinner KA \& Challis JRG 1985 Changes in the synthesis and metabolism of prostaglandins by human-fetal membranes and decidua at labor. American Journal of Obstetrics and Gynecology 151 519-523. (https:// doi.org/10.1016/0002-9378(85)90281-9)

Slater DM, Dennes WJ, Campa JS, Poston L \& Bennett PR 1999 Expression of cyclo-oxygenase types-1 and -2 in human myometrium throughout pregnancy. Molecular Human Reproduction 5 880-884. (https://doi. org/10.1093/molehr/5.9.880)
Sugimoto Y, Yamasaki A, Segi E, Tsuboi K, Aze Y, Nishimura T, Oida H, Yoshida N, Tanaka T, Katsuyama M et al. 1997 Failure of parturition in mice lacking the prostaglandin F receptor. Science 277 681-683. (https://doi.org/10.1126/science.277.5326.681)

Thomson AJ, Telfer JF, Young A, Campbell S, Stewart CJ, Cameron IT, Greer IA \& Norman JE 1999 Leukocytes infiltrate the myometrium during human parturition: further evidence that labour is an inflammatory process. Human Reproduction 14 229-236. (https://doi.org/10.1093/ humrep/14.1.229)

Tsatas D, Baker MS \& Rice GE 1999 Differential expression of proteases in human gestational tissues before, during and after spontaneous-onset labour at term. Journal of Reproduction and Fertility 116 43-49. (https:// doi.org/10.1530/jrf.0.1160043)

Vadillo-Ortega F \& Estrada-Gutierrez G 2005 Role of matrix metalloproteinases in preterm labour. BJOG 112 (Supplement 1) 19-22. (https://doi.org/10.1111/j.1471-0528.2005.00579.x)

Vink J \& Myers K 2018 Cervical alterations in pregnancy. Best Practice and Research: Clinical Obstetrics and Gynaecology 52 88-102. (https://doi. org/10.1016/j.bpobgyn.2018.03.007)

Wall C, Lim R, Poljak M \& Lappas M 2013 Dietary flavonoids as therapeutics for preterm birth: luteolin and kaempferol suppress inflammation in human gestational tissues in vitro. Oxidative Medicine and Cellular Longevity 2013 485201. (https://doi.org/10.1155/2013/485201)

Weiss A, Goldman S \& Shalev E 2007 The matrix metalloproteinases (MMPS) in the decidua and fetal membranes. Frontiers in Bioscience $\mathbf{1 2}$ 649-659. (https://doi.org/10.2741/2089)

Wendel HG, Stanchina ED, Fridman JS, Malina A, Ray S, Kogan S, CordonCardo C, Pelletier J \& Lowe SW 2004 Survival signalling by Akt and elF4E in oncogenesis and cancer therapy. Nature 428 332-337. (https:// doi.org/10.1038/nature02369)

Wenstrom KD, Andrews WW, Hauth JC, Goldenberg RL, Dubard MB \& Cliver SP 1998 Elevated second-trimester amniotic fluid interleukin-6 levels predict preterm delivery. American Journal of Obstetrics and Gynecology 178 546-550. (https://doi.org/10.1016/s00029378(98)70436-3)

Wijesuriya YK \& Lappas M 2018 Potent anti-inflammatory effects of honokiol in human fetal membranes and myometrium. Phytomedicine 49 11-22. (https://doi.org/10.1016/j.phymed.2018.06.004)

Xu P, Alfaidy N \& Challis JR 2002 Expression of matrix metalloproteinase (MMP)-2 and MMP-9 in human placenta and fetal membranes in relation to preterm and term labor. Journal of Clinical Endocrinology and Metabolism 87 1353-1361. (https://doi.org/10.1210/jcem.87.3.8320)

Yellon SM 2017 Contributions to the dynamics of cervix remodeling prior to term and preterm birth. Biology of Reproduction 96 13-23. (https:// doi.org/10.1095/biolreprod.116.142844)

Zhan Y, Dahabieh MS, Rajakumar A, Dobocan MC, M'boutchou MN, Goncalves C, Lucy SL, Pettersson F, Topisirovic I, Van Kempen L et al. 2015 The role of elF4E in response and acquired resistance to vemurafenib in melanoma. Journal of Investigative Dermatology 135 1368-1376. (https://doi.org/10.1038/jid.2015.11)

Received 3 May 2020

First decision 22 May 2020

Revised manuscript received 29 june 2020

Accepted 17 July 2020 